\title{
CNT supported $\mathrm{Mo}_{\mathrm{x}} \mathrm{C}$ catalysts: Impact of loading and carburization parameters
}

\author{
Benjamin Frank, Klaus Friedel, Frank Girgsdies, Xing Huang, Robert Schlögl, and \\ Annette Trunschke*
}

$\mathrm{Mo}_{x} \mathrm{C} / \mathrm{CNT}$ catalysts were prepared by carburization of an oxidic Mo precursor impregnated on multiwalled carbon nanotubes (CNTs). The effects of different carburization atmospheres, heating rates, and Mo loadings were tested. The catalysts were characterized by CO-TPD, $\mathrm{XRD}, \mathrm{N}_{2}$ physisorption, SEM, and TEM. The catalytic performance in the steam reforming of methanol (SRM) was used as a sensitive probe to indicate changes in the catalyst surface during catalytic action. Contrarily to the bulk $\mathrm{Mo}_{\mathrm{x}} \mathrm{C}$ catalysts the heating rate during carburization has practically no effect on the catalysts. Instead, Mo loading and carburization atmosphere are the key factors for catalyst

\section{Introduction}

Group VI transition metal carbides provide catalytic features similar to expensive noble metals, ${ }^{[1]}$ thus are permanently in the focus of intensive research. The high potential in reactions that involve the transfer of hydrogen, such as alkane (de)hydrogenations or isomerizations, ammonia decomposition, and Fischer-Tropsch synthesis has been documented. ${ }^{[2]}$

As the conventional metallurgical route to metal carbides typically provides very low specific surface areas (SSA), the first successful synthesis of high-surface area carbides by carburization of an oxidic precursor ${ }^{[3]}$ was a break-through for catalytic application. However, the synthesis of porous carbides is demanding and it seems more appropriate to utilize a high surface area support such as alumina or carbon to stabilize highly dispersed carbide (nano)particles. ${ }^{[4-6]}$ Carbon-based support materials can also serve as the carbon source for carburization. This economic strategy furthermore avoids the formation of passivating carbon deposits on the catalytically active carbide surface at the end of the carburization process, which easily occurs when using a gaseous hydrocarbon as the carbon source.

Few $\mathrm{Mo}_{\mathrm{x}} \mathrm{C} / \mathrm{C}$ catalysts have been reported in literature ${ }^{[6-9]}$ The carburization in $\mathrm{CH}_{4} / \mathrm{H}_{2}$ mixtures typically leads to well dispersed $\mathrm{Mo}_{\mathrm{x}} \mathrm{C}$ nanoparticles if the surface is sufficiently functionalized. ${ }^{[6,7]}$ The synthesis of multiwalled CNT-supported $\beta$ $\mathrm{Mo}_{2} \mathrm{C}$ has been described by Bao et al. ${ }^{[6]}$ They also highlighted the positive impact of nitric acid treatment of the CNT support prior to its impregnation with the Mo precursor. The abundance of surface oxygen groups created here enables a sufficient metalsupport interaction to avoid agglomeration. However, a more systematic study on the influences of, e. g. Mo loading, carburization conditions, or specific surface properties, is still lacking. The variation of loading in a series of activated carbon and $\mathrm{CNT}$ supported $\mathrm{Mo}_{2} \mathrm{C}$ catalysts has been performed by structure and performance. The Mo-based activity decreases at loadings $>10 \mathrm{wt} \%$ at constant product selectivity. The $\mathrm{CO}_{2} / \mathrm{CH}_{4}$ product ratio sensitively indicates changes in the catalyst properties at the loadings $<20 \mathrm{wt} \%$, where the activity is practically constant. Carburization in $20 \% \mathrm{CH}_{4} / \mathrm{H}_{2}$ yields $2 \mathrm{~nm}$ sized crystallites of cubic $\alpha$ MoC. Carburization in pure $\mathrm{H}_{2}$ and in He yields hexagonal $\beta-\mathrm{Mo}_{2} \mathrm{C}$ with a larger particle size. This phase change is documented in a different catalytic performance in terms of activity and $\mathrm{CO}_{2} / \mathrm{CH}_{4}$ selectivity. Thus a multi-parameter toolbox for fine-tuning of catalyst properties is presented.

Solymosi et al. ${ }^{[10]}$ During ethanol decomposition at $723 \mathrm{~K}$ the catalysts initially deactivate within the first $7 \mathrm{~h}$ time-on-stream. Unfortunately, neither steady state data nor different space velocities are reported to compare the patterns of product selectivities at a similar level of ethanol conversion. Furthermore, the study misses substantial parts of physico-chemical characterization of the samples, thus published data are difficult to interpret and do not support a structure-reactivity-correlation with regard to a catalyst optimization. However, a Mo loading in the range up to $17 \mathrm{wt} \%$, depending on SSA of the support, has been shown to yield finely dispersed $\beta-\mathrm{Mo}_{2} \mathrm{C}$ nanoparticles. This is in good agreement with theoretical considerations: At optimum (maximum) loading the good wetting ability of $\mathrm{MoO}_{3}{ }^{[11]}$ would ideally lead to a homogeneous monolayer coverage of $\sim 5.0$ atoms Mo per square nanometer ${ }^{[12]}$ as the prerequisite for finely dispersed carbide particles. Given a SSA of $300 \mathrm{~m}^{2} \mathrm{~g}^{-1}$ of a carbon support material this corresponds to a $\mathrm{Mo}_{\mathrm{x}} \mathrm{C}$ loading of approx. $20 \mathrm{wt} \%$.

The carburization conditions are predominantly discussed for bulk carbides. ${ }^{[13]}$ Here a comparison of $\mathrm{CH}_{4} / \mathrm{H}_{2}$ and $\mathrm{C}_{2} \mathrm{H}_{6} / \mathrm{H}_{2}$ atmospheres shows that the formation of the carbide phase occurs slower in the presence of $\mathrm{CH}_{4},{ }^{[14]}$ which is the most stable alkane. On the other hand, the higher alkanes tend to easily decompose and favour coke deposition as an overlayer on the carbide particles. In the same study, the variation of the heating rate during carburization reveals that the lower rates enable the

[a] Dr. B. Frank, K. Friedel, Dr. F. Girgsdies, X. Huang, Prof. Dr. R. Schlögl, Dr. A. Trunschke

Department of Inorganic Chemistry

Fritz Haber Institute of the Max Planck Society

Faradayweg 4-6

Fax: (+) 493084134405

E-mail: trunschke@fhi-berlin.mpg.de

Supporting information for this article is available on the WWW under http://dx.doi.org/10.1002/cctc. 200xxxxxx. 
carbide formation process to occur at lower temperatures. It is discussed that soot deposit is the active form of carbon and that then an interfacial reaction sets in driving $C$ into Mo, which could explain the kinetic control of carburization. For low-temperature carburization Mo bronzes are required as intermediates in the topotactic transformation. Such mechanism is of particular interest when using a carbon-based support material itself, such as CNTs. Unfortunately, Hanif et al. do not report surface areas in their study, ${ }^{[14]}$ however, according to the lower concentration of the carburization by-product $\mathrm{H}_{2} \mathrm{O}$, also a structural benefit is expected from low heating rates. The phenomenon of hydrothermal sintering is well known from the reduction process of Fe-based catalysts for ammonia synthesis. ${ }^{[15]}$ Both, the lower heating rate and a higher space velocity of the $\mathrm{CH}_{4} / \mathrm{H}_{2}$ flow effectively lower the $\mathrm{H}_{2} \mathrm{O}$ concentration and at least for the bulk systems a strong structural impact is reported for $\mathrm{Mo}_{x} \mathrm{C}$ and $\mathrm{Mo}_{x} \mathrm{~N}$ systems. ${ }^{[16,17]}$ However, also adverse effects are observed ${ }^{[18]}$ pointing at the high complexity of involved topotactical transformations, which are not fully understood.

\section{Results and Discussion}

\section{Standard parameters and general observations}

The standard MoC/oCNT system serving as the reference during all the catalyst modifications performed is the mediumloaded 20MoC/oCNT carburized in $\mathrm{CH}_{4} / \mathrm{H}_{2}$ at a heating rate of 5 $\mathrm{K} \mathrm{min}^{-1}$. As described in the introduction, a high concentration of well dispersed Mo species is expected here. Numerous reports confirm the complete carburization of oxidic Mo precursors in this atmosphere at $700^{\circ} \mathrm{C},{ }^{[6,14,19]}$ thus ramping has been stopped at this temperature.
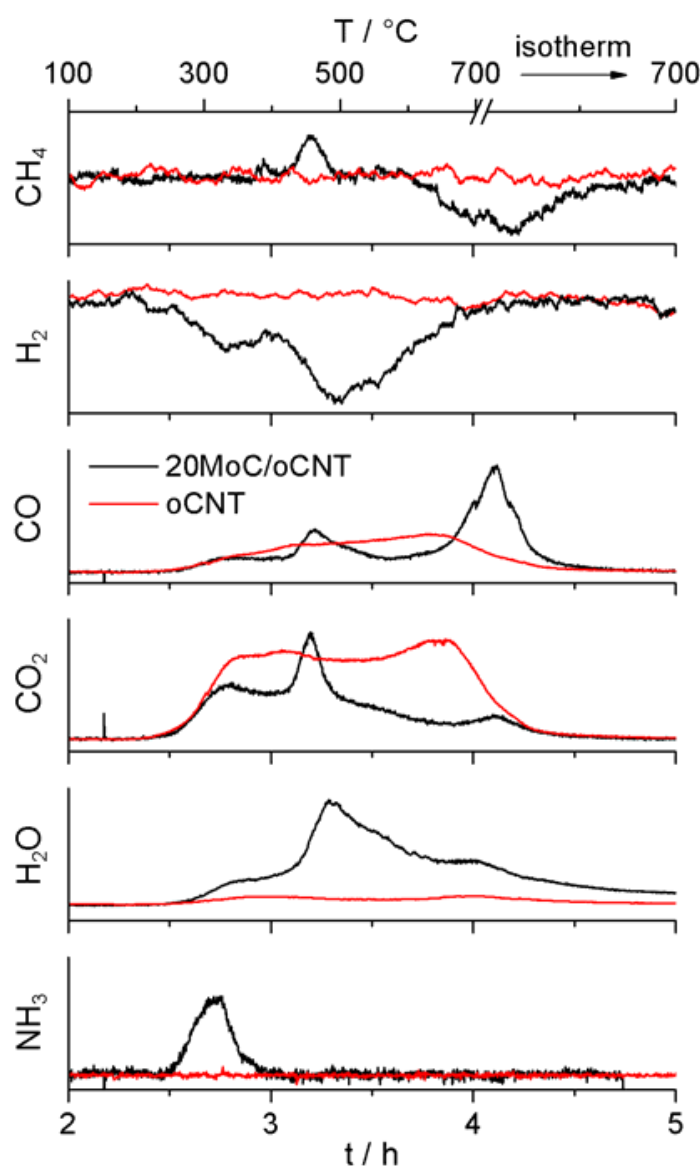

Figure 1. Profiles of $\mathrm{CH}_{4}$ and $\mathrm{H}_{2}$ consumption as well as of $\mathrm{CO}, \mathrm{CO}_{2}, \mathrm{H}_{2} \mathrm{O}$, and $\mathrm{NH}_{3}$ formation during the carburization of 20MoC/oCNT and oCNT samples in $20 \% \mathrm{CH}_{4} / \mathrm{H}_{2}$ at $5 \mathrm{~K} \mathrm{~min}^{-1}$ (after drying in $\mathrm{CH}_{4} / \mathrm{H}_{2}$ at $100^{\circ} \mathrm{C}$ for $2 \mathrm{~h}$ ). The profiles in arbitrary units are normalized with respect to the carbon mass of the sample.

The gases evolving during the carburization of $20 \mathrm{MoC} / \mathrm{oCNT}$ are shown in Fig. 1. Due to the overlap with compounds being released from the metal-free oxidized carbon surface the blank oCNT is given as a reference. According to the traces of $\mathrm{H}_{2}$ and $\mathrm{CH}_{4}$ consumption as well as those of $\mathrm{H}_{2} \mathrm{O}, \mathrm{CO}$, and $\mathrm{CO}_{2}$ formation the following transformations can be assigned to the features observed: (i) decomposition of the ammonium heptamolybdate (AHM) precursor into $\mathrm{MoO}_{3}$, (ii) reduction of $\mathrm{MoO}_{3}$ to $\mathrm{MoO}_{2}$, (iii) partial carburization of $\mathrm{MoO}_{2}$ into a nonstochiometric oxycarbide $\mathrm{MoO}_{\mathrm{x}} \mathrm{C}_{\mathrm{y}}$, and (iv) complete carburization of $\mathrm{MoO}_{x} \mathrm{C}_{y}$ into $\mathrm{Mo}_{x} \mathrm{C}$. These steps are described extensively in literature, ${ }^{[6,14,19]}$ where intermediate phases are identified by $X$-ray diffraction (XRD). In Fig. 1 step (i) can be located in the temperature range of $250-400^{\circ} \mathrm{C}$, where the formation of $\mathrm{NH}_{3}$ and $\mathrm{H}_{2} \mathrm{O}$, respectively, is detected. $\mathrm{H}_{2} \mathrm{O}$ also evolves from the blank oCNT surface, however, to a much lesser extent than over the AHM loaded sample. The (partial) instantaneous reduction of $\mathrm{Mo}^{6+}$ into $\mathrm{Mo}^{4+}$ by $\mathrm{H}_{2}$ is suggested by a weak drop of the $\mathrm{H}_{2}$ profile, which is not observed for the oCNT sample. $\mathrm{CO}_{2}$ and $\mathrm{CO}$ are massively released from the oxidized carbon surface due to the thermal decomposition of carboxylic acid and anhydride groups in this temperature range. ${ }^{[20]}$ Step (ii) is the reduction of $\mathrm{MoO}_{3}$ to $\mathrm{MoO}_{2}$ at $400-500^{\circ} \mathrm{C}^{[14]}$ by both $\mathrm{H}_{2}$ and carbon atoms from the CNT surface. The first is supported by an enhanced $\mathrm{H}_{2}$ consumption under $\mathrm{H}_{2} \mathrm{O}$ release; the latter is indicated by a sharp peak in both the $\mathrm{CO}$ and $\mathrm{CO}_{2}$ profiles at $450^{\circ} \mathrm{C}$, while no $\mathrm{CH}_{4}$ is consumed here. Indeed, $\mathrm{MoO}_{3}$ is well-known as a stochiometric oxidant for elemental carbon. ${ }^{[1]}$ Surprisingly, instead of $\mathrm{CH}_{4}$ consumption a small amount of additional $\mathrm{CH}_{4}$ is generated in the temperature range of step (ii), which is most likely due to the high $\mathrm{CO}_{\mathrm{x}}$ concentrations and the simultaneous presence of $\mathrm{MoO}_{2}$ as a moderate $\mathrm{CO}_{x}$ hydrogenation catalyst. ${ }^{[22]}$ The intermediary formation of an orthorhombic $\mathrm{Mo}_{4} \mathrm{O}_{11}$ phase is also suggested to occur in this temperature range. ${ }^{[13]}$ The dissolution of support (CNT) carbon atoms into $\mathrm{MoO}_{x}$ clusters, which points at defective carbon sites as the oxycarbide nucleation points, should also be considered. ${ }^{[23]}$ Step (iii) covers the temperature range of 500 $650^{\circ} \mathrm{C}$ and is indicated by still heavy, however, slowly declining consumption of $\mathrm{H}_{2}$ under formation of $\mathrm{H}_{2} \mathrm{O}$. Also the $\mathrm{CO}$ and $\mathrm{CO}_{2}$ concentrations are still high, however, this is most likely caused by the steady defunctionalisation oCNT support. ${ }^{[20]}$ The complete transformation into the oxycarbide $\mathrm{MoO}_{x} \mathrm{C}_{y}$ is indicated by the finished $\mathrm{H}_{2}$ consumption and the onset of $\mathrm{CH}_{4}$ consumption. Finally, step (iv) is characterized by the heavy consumption of $\mathrm{CH}_{4}$ under formation of $\mathrm{CO}, \mathrm{CO}_{2}$, and $\mathrm{H}_{2} \mathrm{O}$, which all slowly decay until the end of the carburization process after $1 \mathrm{~h}$ at $700^{\circ} \mathrm{C}$.

It is noteworthy that the formation of $\mathrm{CO}$ and $\mathrm{CO}_{2}$ from the blank oCNT sample temporarily exceeds their release from $20 \mathrm{MoC} / \mathrm{oCNT}$. This can be referred to the strong metal-support interaction between Mo species and the oxygen functionalities created on the carbon surface to anchor and disperse the AHM precursor as well as intermediate species. As suggested by Fig. 1, a substantial fraction of $\mathrm{O}$ atoms from the carbon surface are finally converted into $\mathrm{H}_{2} \mathrm{O}$.

Temperature-programmed desorption (TPD) of $\mathrm{CO}$ was directly performed on the freshly carburized catalysts without exposition to ambient $\mathrm{O}_{2}$ and $\mathrm{H}_{2} \mathrm{O}$. Two main peaks at around 120 and a shoulder at $200^{\circ} \mathrm{C}$ are observed (Supporting Information, Fig. S1). The comparison with the blank oCNT material proves 
that the CO profile exclusively originates from the interaction of $\mathrm{CO}$ with the $\mathrm{Mo}_{\mathrm{x}} \mathrm{C}$ particles. In particular Yang et al. in their FTIR supported study of $\mathrm{CO}$ adsorption on MoN assigned peaks at similar positions to the desorption of $\mathrm{CO}$ from $\mathrm{Mo}^{\delta+}(0<\delta<2)$ and $\mathrm{N}$ sites, respectively. ${ }^{[24]}$ Due to the structurally and catalytically similar properties between Mo carbides and nitrides this assignment is tentatively adapted to $\mathrm{Mo}_{\mathrm{x}} \mathrm{C}$ depending on the surface termination by $\mathrm{Mo}$ or by $\mathrm{C}$ (instead of $\mathrm{N}$ ). Indeed, for $\beta-\mathrm{Mo}_{2} \mathrm{C}(0001)$ theory predicts quite similar stabilities of $\mathrm{CO}$ adsorbed on the top positions (t1) on C- and on Mo-terminated surfaces, respectively. ${ }^{[25]}$ The total amount of $\mathrm{CO}$ desorbed up to $500^{\circ} \mathrm{C}$ is $332 \mu \mathrm{mol}$ $\mathrm{g}\left(\mathrm{Mo}_{\mathrm{x}} \mathrm{C}\right)^{-1}$. This value appears rather low, however, it is reported that $\mathrm{CO}$ chemisorption on $\mathrm{Mo}_{x} \mathrm{C}$ at ambient temperature only measures $\sim 14 \%$ of total adsorption sites. ${ }^{[26]}$ Thus, the mean $\mathrm{Mo}_{\mathrm{x}} \mathrm{C}$ particle diameter can be estimated as $\sim 5 \mathrm{~nm} .{ }^{[27]}$

Steam reforming of methanol (SRM) was chosen as a probe reaction due to a complex selectivity pattern, which is expected to sensitively indicate changes in the catalyst structure. In the reaction network of SRM, $\mathrm{MeOH}$ can react to $\mathrm{CO}_{2}$ or $\mathrm{CO},{ }^{[28]}$ which in the presence of $\mathrm{H}_{2}$ can further react to $\mathrm{CH}_{4}$ and higher alkanes/alkenes via Fischer Tropsch synthesis over Mo-based catalysts. ${ }^{[29]}$

The $20 \mathrm{MoC} / \mathrm{oCNT}$ catalyst approaches a stable catalytic performance after $2 \mathrm{~h}$ time-on-stream at $250^{\circ} \mathrm{C}$ and only minor deactivation is observed in a $24 \mathrm{~h}$ test run. The conversion $X$ of $\mathrm{MeOH}$ over this catalyst as a function of contact time is shown in the Supporting Information (Fig. S2a). The rapid increase in conversion is followed by a slow-down of the reaction rate after reaching approx. $50 \%$ conversion. This may be referred to inhibition by the main reaction products $\mathrm{H}_{2}$ and $\mathrm{CO}_{2}$ as observed over Cu-based catalysts, ${ }^{[30]}$ although the overall reactant concentration is relatively low. The main carbon-based products of the reaction are $\mathrm{CO}_{2}$ and $\mathrm{CH}_{4}$, whereas $\mathrm{CO}, \mathrm{C}_{2} \mathrm{H}_{6}$, and $\mathrm{C}_{2} \mathrm{H}_{4}$ are formed only in trace amounts. The following reactions are expected to predominantly contribute to the product pattern observed:

(1) methanol steam reforming $\mathrm{CH}_{3} \mathrm{OH}+\mathrm{H}_{2} \mathrm{O} \rightarrow \mathrm{CO}_{2}+3 \mathrm{H}_{2}\left(\Delta H^{0}=49.6 \mathrm{~kJ} \mathrm{~mol}^{-1}\right)$

(2) methanol reduction $\mathrm{CH}_{3} \mathrm{OH}+\mathrm{H}_{2} \rightarrow \mathrm{CH}_{4}+\mathrm{H}_{2} \mathrm{O}\left(\Delta H^{0}=-115.4 \mathrm{~kJ} \mathrm{~mol}^{-1}\right)$

(3) methanol decomposition $\mathrm{CH}_{3} \mathrm{OH} \rightarrow \mathrm{CO}+2 \mathrm{H}_{2}\left(\Delta H^{0}=90.6 \mathrm{~kJ} \mathrm{~mol}^{-1}\right)$

(4) reverse water gas shift $\mathrm{CO}_{2}+\mathrm{H}_{2} \rightarrow \mathrm{CO}+\mathrm{H}_{2} \mathrm{O}\left(\Delta H^{0}=41.1 \mathrm{~kJ} \mathrm{~mol}^{-1}\right)$

(5) $\mathrm{CO}_{x}$ hydrogenation $\mathrm{CO}_{\mathrm{x}}+\mathrm{H}_{2} \rightarrow$ alkanes/alkenes $+\mathrm{H}_{2} \mathrm{O}$

In general, these observations agree with a previous report on supported $\mathrm{Mo}_{2} \mathrm{C}$ catalysts. ${ }^{[30,31]}$ However, the detailed comparison of SRM activity fails due to different reaction conditions applied. The metal-free oCNT shows no catalytic activity under the reaction conditions applied.

Three parameters have been selected here to quantify changes in the catalytic performance of MoC/oCNT catalysts, namely the apparent activation energies of $\mathrm{CO}_{2}$ and $\mathrm{CH}_{4}$ formation, respectively, and the $\mathrm{CO}_{2} / \mathrm{CH}_{4}$ product ratio (see Tab. 2). For $20 \mathrm{MoC} / \mathrm{oCNT}$ carburized in $\mathrm{CH}_{4} / \mathrm{H}_{2}$ at a heating rate of $5 \mathrm{~K} \mathrm{~min}^{-1}$ the activation energies are $94 \mathrm{~kJ} \mathrm{~mol}^{-1}$ and $108 \mathrm{~kJ} \mathrm{~mol}^{-1}$, respectively, and a product ratio of 4.1 . The $\mathrm{CO}_{2} / \mathrm{CH}_{4}$ ratio as a function of $\mathrm{MeOH}$ conversion (see the Supporting Information, Fig S2b) suggests that both $\mathrm{CO}_{2}$ and $\mathrm{CH}_{4}$ are primary products of the reaction; however, secondary methanation of $\mathrm{CO}_{2}$ also occurs.

After SRM tests the catalyst samples were characterized by $X R D, \mathrm{~N}_{2}$-physisorption, and electron microscopy. Due to the contact with $\mathrm{H}_{2} \mathrm{O}$ and $\mathrm{CO}_{2}$ acting as mildly oxidizing agents ${ }^{[33]}$ during SRM no surface passivation by low-concentrated $\mathrm{O}_{2}$ was needed prior to exposition to ambient conditions. XRD confirms the pervasive transformation of AHM into face-centered cubic (fcc) $\alpha$-MoC (Supporting Information, Fig. S3a). Although the catalyst has been used in a catalytic reaction involving potential oxidants such as $\mathrm{H}_{2} \mathrm{O}$ or $\mathrm{CO}_{2}$ and even after long-term exposition to ambient conditions the patterns give no rise to oxidic bulk phases. As a reference, the pattern of molybdenum oxycarbide $\mathrm{MoOC}$ is characterized by a shift of the fcc pattern to higher angles, ${ }^{[34]}$ which is indicative for a lattice contraction as a result of partial C-O-substitution. This is not the case here, where the detected peaks fall in line with the reference pattern for $\alpha-M o C .{ }^{[35]}$ Peak analysis reveals a crystallite size of approx. $2 \mathrm{~nm}$. The reason for the formation of the metastable ${ }^{[35,36]}$ fcc $\alpha-\mathrm{MoC}$ instead of hexagonal close packed (hcp) $\beta-\mathrm{Mo}_{2} \mathrm{C}$, which is predominantly reported to form under the synthesis conditions applied, ${ }^{[3,4,6,13,14,32]}$ is not fully understood. Initially formed nuclei of sub-carbides or $\alpha$ MoC may be formed at low temperatures, where the thermodynamic equilibration of the phases is inhibited for diffusion limitation, and prevail during synthesis. This is evidenced by the pronounced polycrystallinity of the material as described later. Han et al. suggest that the $\mathrm{Mo}_{x} \mathrm{C}$ phase can be controlled over the Mo loading on an ordered mesoporous carbon (OMC) support. ${ }^{[8]}$ However, presented XRD diffractograms are difficult to interpret. It is more likely that the controlled reduction of the Mo precursor is the key factor for $\alpha-M o C$ synthesis. This has been successfully managed by $\mathrm{MoO}_{3}$ pre-reduction in a $\mathrm{H}_{2} / n$ butane mixture ${ }^{[37]}$ or by adding $0.5 \% \mathrm{Pt}$ to the Mo precursor to facilitate $\mathrm{H}_{2}$ activation. ${ }^{[38]} \alpha$-MoC proved a differrent performance than $\beta-\mathrm{Mo}_{2} \mathrm{C}$ in some catalytic reactions ${ }^{[9,36,38]}$ and is traditionally prepared via nitridation of $\mathrm{MoO}_{3}$ with $\mathrm{NH}_{3}$ to fcc $\gamma-\mathrm{Mo}_{2} \mathrm{~N}$ followed by subsequent re-carburization with $\mathrm{CH}_{4}$, which is a time- and resource-demanding process. ${ }^{[38]}$ In this context the one-step preparation of CNT-supported $\alpha-\mathrm{MoC}$ is a valuable observation.

The specific surface area of the catalyst drops from 290 to $163 \mathrm{~m}^{2} \mathrm{~g}^{-1}$ if compared to the metal-free oCNT (Tab. 1). This is most likely caused by plugging of open CNT tips by agglomerates of $\alpha$-MoC. The XRD observations are in good agreement with the $\alpha-\mathrm{MoC}$ particle size that is estimated by CO TPD.

\section{Impact of the heating rate during carburization}

It is reported that the heating rate during the carburization of the metal carbide precursor can control the phase transformation temperatures and the pore structure of the resulting (bulk) carbide. Both effects are discussed for CNT supported systems at a nominal $\mathrm{Mo}_{x} \mathrm{C}$ loading of $20 \mathrm{wt} \%$. The heating rates were varied in the range of 0.2 to $10 \mathrm{~K} \mathrm{~min}^{-1}$. For comparison the profiles of $\mathrm{H}_{2} \mathrm{O}$ evolution are assembled in Fig. 2 .

Fig. 2 reveals a dramatic impact of the heating rate on the carburization process. If referred to the temperature, peaks are sharp and well resolved at the lowest heating rate of $0.2 \mathrm{~K} \mathrm{~min}^{-1}$. Here, the reaction is completed at approx. $600^{\circ} \mathrm{C}$, however, on the cost of a reaction time of almost $50 \mathrm{~h}$. Contrarily, at the highest heating rate of $10 \mathrm{~K} \mathrm{~min}^{-1}$ peaks are broad and superimposed by each other. The release of $\mathrm{H}_{2} \mathrm{O}$ approaches zero not before $1 \mathrm{~h}$ heat treatment in the $\mathrm{CH}_{4} / \mathrm{H}_{2}$ atmosphere. Nevertheless all the features observed at $0.2 \mathrm{~K} \mathrm{~min}^{-1}$ can also be identified 
here, indicating the successful carburization via the same intermediate phases in all the experiments.

The CO TPD (Supporting Information, Fig. S1) reveals no substantial differences between the 20MoC/oCNT samples carburized at different heating rates. The high-temperature shoulder is slightly more intense for the sample carburized at $1 \mathrm{~K}$ $\mathrm{min}^{-1}$. The amount of $\mathrm{CO}$ desorbed up to $500^{\circ} \mathrm{C}$ varies in the range of $330-380 \mu \mathrm{mol} g\left(\mathrm{Mo}_{x} \mathrm{C}\right)^{-1}$ (Tab. 1) corresponding to a $\mathrm{Mo}_{\mathrm{x}} \mathrm{C}$ particle size of $4-5 \mathrm{~nm}$. Also the specific surface areas of the samples are very similar with a very weak tendency to the higher values at the lower heating rates. Partial methanation of the carbon support ${ }^{[40]}$ to create a more defective surface or improved spreading of the Mo precursor during the protracted carburization process ${ }^{[11]}$ might be the reasons for this observation.

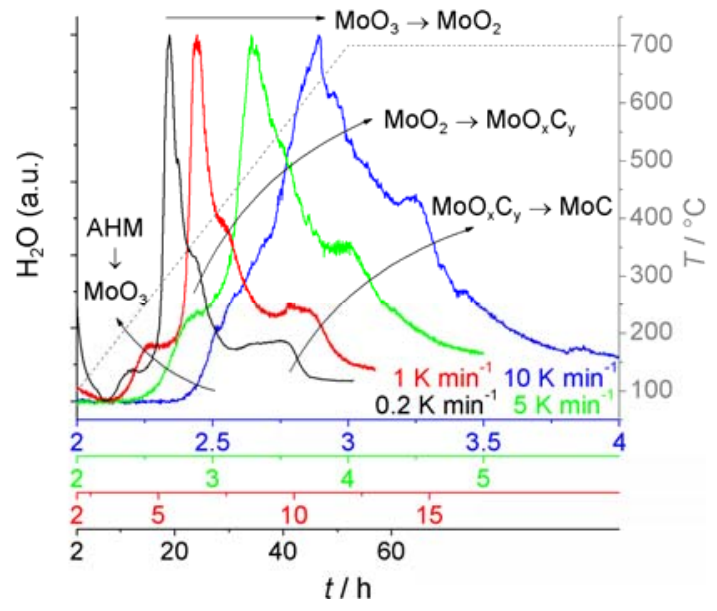

Figure 2. Profiles of $\mathrm{H}_{2} \mathrm{O}$ desorption during carburization of $20 \mathrm{MoC} / \mathrm{oCNT}$ at different heating rates (after drying in $\mathrm{CH}_{4} / \mathrm{H}_{2}$ at $100^{\circ} \mathrm{C}$ for $2 \mathrm{~h}$ ). The m/e 18 traces are normalized for intensity and temperature

\begin{tabular}{|lllll|}
\hline \multicolumn{4}{|c|}{ Table 1. Physico-chemical characterization of Mox $\mathrm{C}$ CNT catalysts } \\
\hline Sample & $\begin{array}{l}\beta^{[a]} \\
/ \mathrm{K} \mathrm{min}^{-1}\end{array}$ & Atmosphere & $\begin{array}{l}\mathrm{SSA} \\
/ \mathrm{m}^{2} \mathrm{~g}^{-1}\end{array}$ & $\begin{array}{l}\mathrm{CO} / \mu \mathrm{mol} \\
\mathrm{g}\left(\mathrm{Mo}_{\mathrm{x}} \mathrm{C}\right)^{-1}\end{array}$ \\
\hline oCNT & 5 & $\mathrm{CH}_{4} / \mathrm{H}_{2}$ & 290 & 0 \\
\hline 20MoC/oCNT & 0.2 & $\mathrm{CH}_{4} / \mathrm{H}_{2}$ & 172 & 332 \\
20MoC/oCNT & 1 & $\mathrm{CH}_{4} / \mathrm{H}_{2}$ & 169 & 379 \\
20MoC/oCNT & 5 & $\mathrm{CH}_{4} / \mathrm{H}_{2}$ & 163 & 332 \\
20MoC/oCNT & 10 & $\mathrm{CH}_{4} / \mathrm{H}_{2}$ & 163 & 346 \\
\hline 5MoC/oCNT & 5 & $\mathrm{CH}_{4} / \mathrm{H}_{2}$ & 245 & 509 \\
10MoC/oCNT & 5 & $\mathrm{CH}_{4} / \mathrm{H}_{2}$ & 197 & 391 \\
30MoC/oCNT & 5 & $\mathrm{CH}_{4} / \mathrm{H}_{2}$ & 128 & 229 \\
\hline 20MoC/oCNT & 5 & $\mathrm{H}_{2}$ & 170 & 143 \\
20MoC/oCNT & 5 & $\mathrm{He}$ & 146 & 66 \\
\hline
\end{tabular}

[a] heating rate during carburization.

The similar catalytic performance in the SRM reaction (Supporting information, Tab. S1) suggests only minor differences in the catalyst structure according to the variation of the heating rate during carburization. The activities for methanol conversion at $250^{\circ} \mathrm{C}$ are almost identical (Supporting information, Fig. S2a). The apparent activation energies of $\mathrm{CO}_{2}$ and $\mathrm{CH}_{4}$ formation appear unaffected in the ranges of 91-95 and $108 \mathrm{~kJ} \mathrm{~mol}^{-1}$, respectively. Accordingly, the $\mathrm{CO}_{2} / \mathrm{CH}_{4}$ product ratio is fixed at around $4-5$. The catalyst carburized at the lowest heating rate of $0.2 \mathrm{~K} \mathrm{~min}^{-1}$ shows a weakly enhanced ratio of 5.1 (Supporting information, Fig. S2b), which is in agreement with a somewhat lower apparent activation energy of $\mathrm{CO}_{2}$ formation.

Post-catalytic sample analysis by XRD reveals the presence of $\alpha$-MoC nanocrystallites ( $2 \mathrm{~nm}$ ). The diffractograms are almost congruent (Supporting information, Fig. S3b) and free of reflexes other than $\alpha-\mathrm{MoC}$ and graphitic CNTs. This finally proves that the heating rate during carburization in $\mathrm{CH}_{4} / \mathrm{H}_{2}$ in the range of $0.2-10$ $\mathrm{K} \mathrm{min}^{-1}$ has practically no effect on the structure and catalytic performance of $20 \mathrm{MoC} / \mathrm{oCNT}$ catalysts. It is again worth mentioning that particles are polycrystals. These originate from frustrated growth at the mild conditions applied and this process is most likely induced by diffusion of defective carbon atoms from the support material into $\mathrm{MoO}_{\mathrm{x}}$ nuclei. ${ }^{[23]}$ The formation of frustrated high-temperature metastable phases as active particles in turn might be the cause of activity and stability of the catalysts. Apparently, these can survive the redox stress during SRM much better than, e.g., single crystal surfaces or high-temperature phases converting into oxycarbides.

\section{Variation of the metal loading of $\mathrm{Mo}_{\mathrm{x}} \mathrm{C} / \mathrm{CNT}$ catalysts}

The metal loading of $\mathrm{MoC} / \mathrm{oCNT}$ catalysts was varied between nominal $\mathrm{Mo}_{x} \mathrm{C}$ contents of $5-30 \mathrm{wt} \%$ to investigate the limits of surface coverage and agglomeration. AHM impregnated samples were carburized in $\mathrm{CH}_{4} / \mathrm{H}_{2}$ at a heating rate of $5 \mathrm{~K} \mathrm{~min}^{-1}$.

The scanning electron microscopy (SEM) study reveals entangled CNTs without any agglomerates indicating the successful dispersion of metal species on the CNT surface. Even on the $30 \mathrm{MoC} / \mathrm{oCNT}$, which is the highest loading tested, bulky $\mathrm{Mo}_{\mathrm{x}} \mathrm{C}$ particles cannot be visualized by SEM (Fig. 3a). The energy-dispersive analysis of X-ray (EDX) quantification of Mo and $\mathrm{O}$ confirms the nominal metal content and also indicates the presence of residual $O$ on the surface of all samples (Fig. 3b). However, the $\mathrm{O}$ content is similar on all the catalysts and as high as on the blank oCNT sample, which similarly has been subjected to the carburization treatment and CO TPD, respectively. Thus, the $O$ can likely be assigned to the metal-free fractions of the carbon surface. Especially the $\mathrm{C}-\mathrm{OH}, \mathrm{C}=\mathrm{O}$, and $\mathrm{C}-\mathrm{O}-\mathrm{C}$ groups formed during initial $\mathrm{HNO}_{3}$ treatment are very stable, ${ }^{[20]}$ thus can resist high temperatures in a reducing atmosphere. 

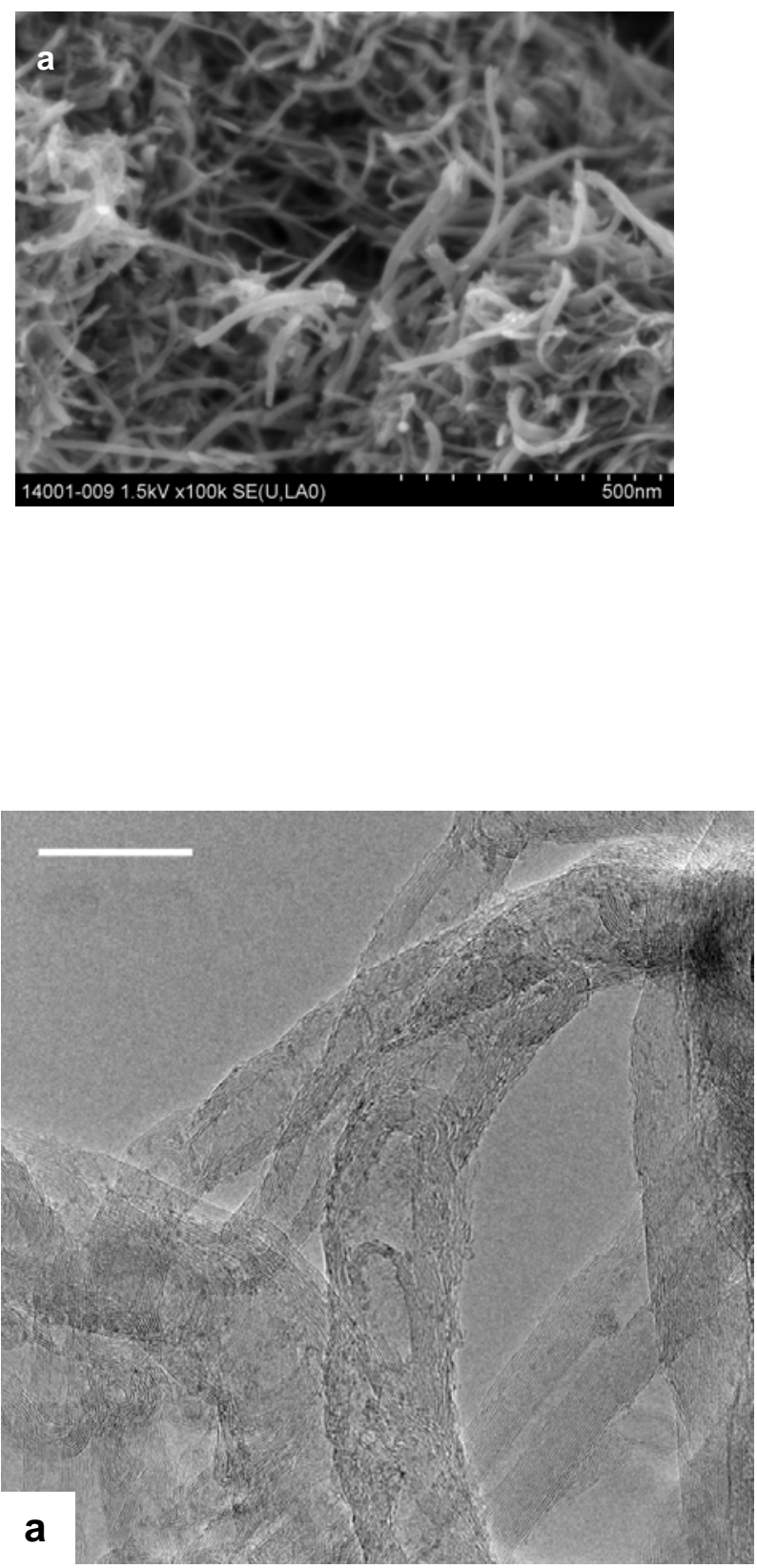

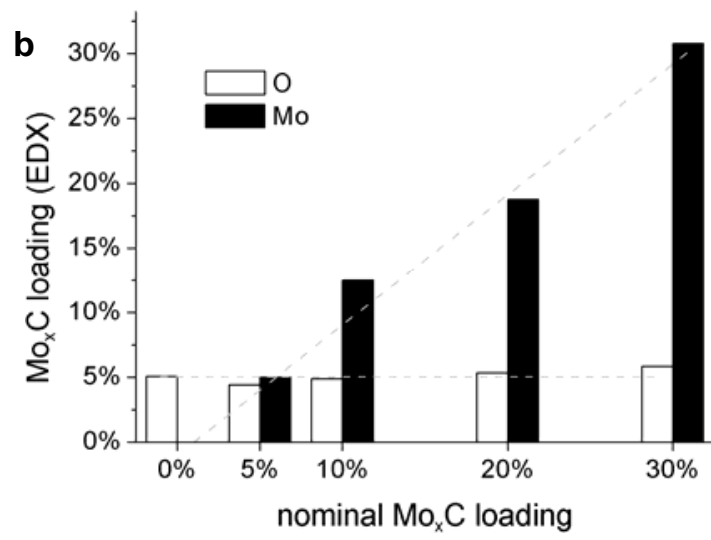

Figure 3. (a) Representative SEM image of $30 \mathrm{MoC} / \mathrm{oCNTS}$ and (b) EDX analysis of MoC/oCNT catalysts. Dashed grey lines represent the parity line $\left(\mathrm{Mo}_{\mathrm{x}} \mathrm{C}\right)$ and the average $(\mathrm{O})$, respectively.

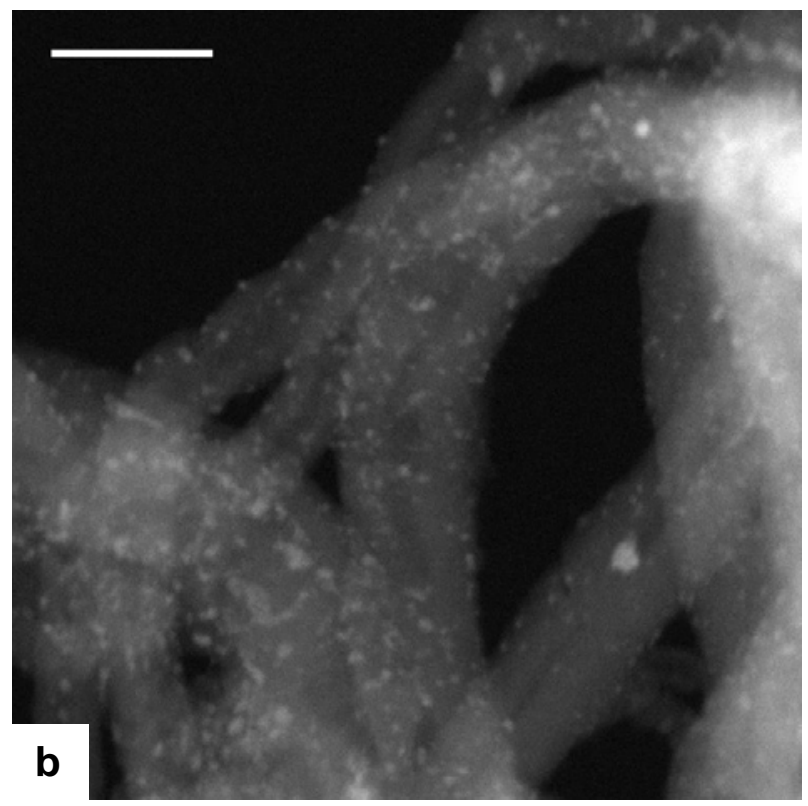

Figure 4. Representative (a) TEM and (b) corresponding HAADF images of the 5MoC/oCNT catalyst after reaction. Scalebar: $20 \mathrm{~nm}$.

Transmission electron microscopy (TEM) gives an impression of the catalyst structure (Fig. 4a). The high dispersion of uniformly sized $\mathrm{Mo}_{\mathrm{x}} \mathrm{C}$ particles is best seen in the scanning mode (STEM) at the lowest loading of $5 \mathrm{wt} \%$. A representative high angle annular dark field (HAADF) image is shown in Fig. 4b. The mean particle size as estimated from these figures is $1-2 \mathrm{~nm}$. At the higher loadings agglomeration of crystallites occurs (see the Supporting Information, Fig. S4). However, the still finely structured agglomerates of small $(<5 \mathrm{~nm}) \alpha$-MoC crystallites are located preferably at the outer CNT surface and at their tips, which were previously opened by harsh $\mathrm{HNO}_{3}$ treatment. They vary in size but rarely exceed a diameter of $10 \mathrm{~nm}$. It is also visible that the CNT structure is intact after the carburization process, which indicates that $\mathrm{CH}_{4}$ rather than the support serves as the main carbon source for $\alpha$-MoC formation.

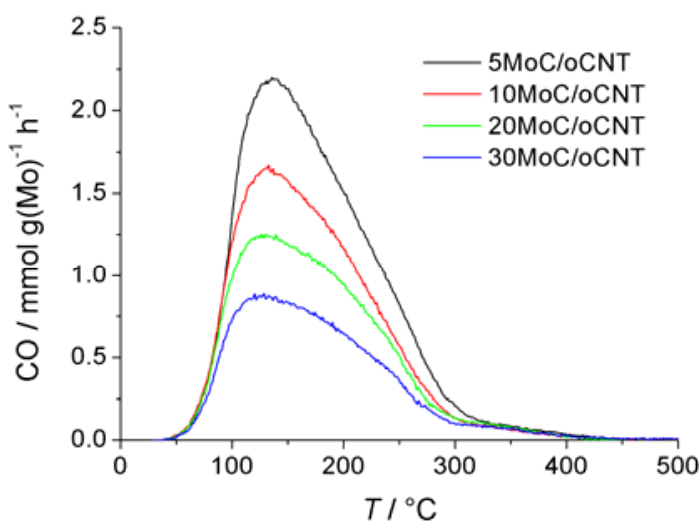

Figure 5. CO TPD profiles of differently loaded MoC/oCNT catalysts. 
The quantitative analysis of CO TPD reveals a strong impact of the $\mathrm{Mo}_{\mathrm{x}} \mathrm{C}$ loading on the amount of $\mathrm{CO}$ desorbed at $<500^{\circ} \mathrm{C}$ (Fig. 5). If referred to the mass of $\mathrm{Mo}_{x} \mathrm{C}$, the low loaded $5 \mathrm{MoC} / \mathrm{OCNT}$ catalyst provides more than twice as much adsorption sites than the highly loaded $30 \mathrm{MoC} / \mathrm{oCNT}$ catalyst (Tab. 1). It indicates that the mean $\mathrm{Mo}_{\mathrm{x}} \mathrm{C}$ particle diameter within the MoC/oCNT loading series varies in the range of 3-7 nm. The detailed analysis of curve shapes in Fig. 5 points at two contributions, as discussed above, for all catalysts. For the loading series the high-temperature shoulder, which is assigned to the $\mathrm{CO}$ adsorption on C-terminated surface sites, is more pronounced at the higher loadings. In particular, the two-component Gaussian fit proves that the fraction of $\mathrm{CO}$ desorbed at $\sim 200^{\circ} \mathrm{C}$ steadily increases from 30 to $45 \%$ as the $\mathrm{Mo}_{\mathrm{x}} \mathrm{C}$ loading increases from 5 to $30 \mathrm{wt} \%$. According to above assumptions this could be interpreted as an increased fraction of $\mathrm{C}$-terminated $\mathrm{Mo}_{\mathrm{x}} \mathrm{C}$ surfaces with the increasing $\mathrm{Mo}_{\mathrm{x}} \mathrm{C}$ loading.

Regarding SRM catalysis two aspects have to be discussed. Firstly, the overall activity in terms of $\mathrm{MeOH}$ conversion (Fig. 6a) is similarly high for low loaded samples ( $\leq 10 \mathrm{wt} \% \mathrm{Mo}_{\mathrm{x}} \mathrm{C}$ ), if referred to the Mo content. The higher metal loadings decrease the effective reaction rate. Possible reasons are mass transport limitations in the high- $\mathrm{Mo}_{x} \mathrm{C}$ catalyst particles being too rich in active sites or larger $\mathrm{Mo}_{x} \mathrm{C}$ particles having a lower specific (active) surface area. The results obtained from CO TPD suggest the latter although even at the low loadings the amount of $\mathrm{CO}$ adsorbed remarkably differs. The second aspect is the $\mathrm{CO}_{2} / \mathrm{CH}_{4}$ product ratio (Fig. 6b). As listed in Tab. 2 the catalyst with the lowest $\mathrm{Mo}_{\mathrm{x}} \mathrm{C}$ loading of $5 \mathrm{wt} \%$ produces only half of the amount of $\mathrm{CH}_{4}$ that is produced over the highly loaded catalysts. The catalysts approach similar selectivities at $\mathrm{Mo}_{\mathrm{x}} \mathrm{C}$ loadings $\geq 20 \mathrm{wt} \%$. The opposite trend has been reported for SRM over $\mathrm{Mo}_{2} \mathrm{C}$ supported on active carbon. ${ }^{[31]} \mathrm{Here}$, the $\mathrm{CO}_{2} / \mathrm{CH}_{4}$ product ratios of 2.5 and 4.1 were measured at $50 \% \mathrm{MeOH}$ conversion over 5 $w t \%$ and $10 \mathrm{wt} \%$ loaded $\mathrm{Mo}_{2} \mathrm{C} / \mathrm{C}$ catalysts, respectively. However, contrarily to the present study, high conversions have been achieved by temperature increase instead of GHSV variation. Thus, higher $\mathrm{CH}_{4}$ selectivities can also be a result of the reaction temperature. For $20 \mathrm{MoC} / \mathrm{oCNT}$ this assumption is exemplarily confirmed by plotting the $\mathrm{CO}_{2} / \mathrm{CH}_{4}$ ratio as a function of $\mathrm{MeOH}$ conversion during the step-wise temperature decrease from 250 $200^{\circ} \mathrm{C}$ for determination of apparent activation energies (Supporting information, Fig. 2b). Indeed, the $\mathrm{CO}_{2} / \mathrm{CH}_{4}$ ratio increases from 4.6 to 6.6 when lowering the temperature in this range, where the impact of conversion on $\mathrm{CO}_{2} / \mathrm{CH}_{4}$ is rather low.
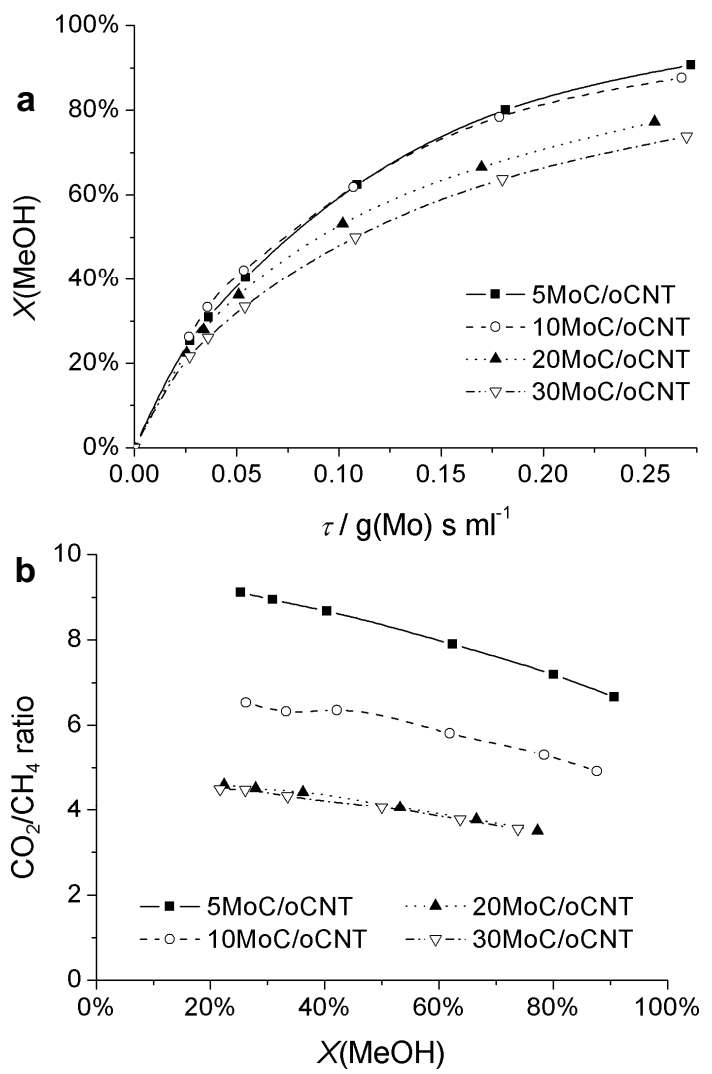

Figure 6. (a) Conversion of $\mathrm{MeOH}$ in the SRM reaction over MoC/oCNT catalysts as a function of the Mo-based contact time. (b) $\mathrm{CO}_{2} / \mathrm{CH}_{4}$ product ratio as a function of $\mathrm{MeOH}$ conversion. Reaction conditions: 167-1000 mg catalyst, 10 $100 \mathrm{ml} \mathrm{min}{ }^{-1}$ of $1 \% \mathrm{MeOH} / 1 \% \mathrm{H}_{2} \mathrm{O} / \mathrm{He}, 250^{\circ} \mathrm{C}$

\begin{tabular}{|c|c|c|c|}
\hline Sample & $E_{\mathrm{a}}\left(\mathrm{CO}_{2}\right) / \mathrm{kJ} \mathrm{mol}^{-1}$ & $E_{\mathrm{a}}\left(\mathrm{CH}_{4}\right) / \mathrm{kJ} \mathrm{mol}^{-1}$ & $S\left(\mathrm{CO}_{2}\right) / S\left(\mathrm{CH}_{4}\right)^{[a]}$ \\
\hline oCNT & $-^{[b]}$ & $\Omega^{[b]}$ & $L^{[b]}$ \\
\hline $5 \mathrm{MoC} / \mathrm{oCNT}$ & $95 \pm 1$ & $111 \pm 1$ & 8.4 \\
\hline 10MoC/oCNT & $93 \pm 2$ & $111 \pm 1$ & 6.1 \\
\hline 15MoC/oCNT & $91 \pm 1$ & $108 \pm 1$ & 4.0 \\
\hline 20MoC/oCNT & $94 \pm 2$ & $108 \pm 2$ & 4.1 \\
\hline 30MoC/oCNT & $92 \pm 2$ & $108 \pm 1$ & 4.1 \\
\hline
\end{tabular}

[a] $250^{\circ} \mathrm{C}, X(\mathrm{MeOH})=50 \%$. [b] no catalytic activity observed.

The specific surface areas of the differently loaded catalysts decrease with the increasing Mo loading and finally approach 128 $\mathrm{m}^{2} \mathrm{~g}^{-1}$ (Tab. 1). It is well explained by the TEM observation of CNT open tips plugging with MoC. At the higher loadings also the mass fraction of MoC providing a lower SSA than the pure CNTs becomes a significant factor. 


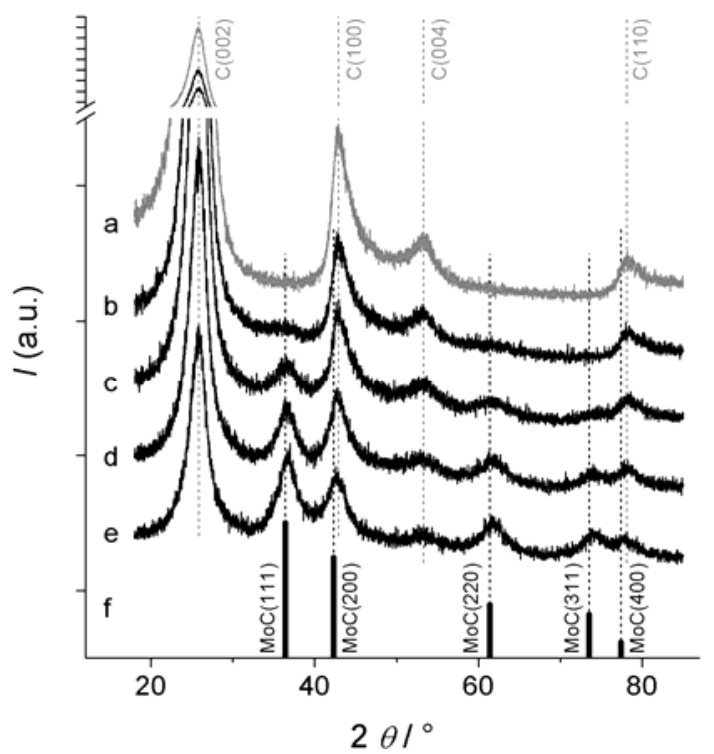

Figure 7. X-ray diffractograms of (a) oCNT and (b-e) Mo $\mathrm{C}$-loaded oCNT catalysts after catalytic reaction (top down: oCNT, 5MoC/oCNT, 10MoC/oCNT, $20 \mathrm{MoC} / \mathrm{oCNT}$, and $30 \mathrm{MoC} / \mathrm{oCNT})$; f) Reference pattern of $\alpha-\mathrm{MoC}^{[34,40]}$

The X-ray diffractograms for the loading series are depicted in Fig. 7. The metal-free oCNT identifies the graphitic reflections originating from the support material. With the increasing Mo loading the pattern is supplemented by adding the reflections of fcc $\alpha$-MoC, which are clearly visible at a $\mathrm{Mo}_{\mathrm{x}} \mathrm{C}$ loading of $\geq 10$ wt $\%$. A superposition appears at around $42-43^{\circ}$ and at $77-78^{\circ}$ with the $\operatorname{MoC}(200) / C(100)$ and $\operatorname{MoC}(400) / C(110)$ reflections, respectively. For all the samples with $\mathrm{Mo}_{\mathrm{x}} \mathrm{C} \geq 10 \mathrm{wt} \%$ the pattern analyses reveal an $\alpha-\mathrm{MoC}$ crystallite diameter of $\sim 2 \mathrm{~nm}$.

\section{Influence of the carburization atmosphere}

The carburization atmosphere can have significant influence on the $\mathrm{Mo}_{x} \mathrm{C}$ phase formed during carburization. Typically, in $\mathrm{CH}_{4} / \mathrm{H}_{2}$ the hcp $\beta-\mathrm{Mo}_{2} \mathrm{C}$ is formed ${ }^{[6]}$ However, Han et al. show that the use of pure $\mathrm{H}_{2}$ at $700^{\circ} \mathrm{C}$ leads to the formation of both $\alpha$ $\mathrm{MoC}$ and $\beta-\mathrm{Mo}_{2} \mathrm{C}$ depending on the Mo concentration on the OMC support, ${ }^{[8]}$ which here serves as the carbon source. They also indicate that the carburization in inert $\mathrm{N}_{2}$ at $700^{\circ} \mathrm{C}$ stops at the partially reduced $\mathrm{MoO}_{2}$. Similar carburization conditions are applied for $20 \mathrm{MoC} / \mathrm{oCNT}$ catalysts.

The carburization profiles monitored in $\mathrm{H}_{2}$ and in inert $\mathrm{He}$ atmospheres, respectively, are shown in Fig. 8. Similar to $\mathrm{CH}_{4} / \mathrm{H}_{2}$ (Fig. 1), carburization starts with the decomposition of the AHM precursor under release of $\mathrm{NH}_{3}$ and $\mathrm{H}_{2} \mathrm{O}$ at $250-350^{\circ} \mathrm{C}$. However, for unknown reason less $\mathrm{H}_{2} \mathrm{O}$ is detected in $\mathrm{H}_{2}$. Here, a subsequent drop of the $\mathrm{H}_{2}$ profile is seen, which is accompanied by steadily increasing $\mathrm{H}_{2} \mathrm{O}$ formation and indicates the reduction of $\mathrm{MoO}_{3}$ into $\mathrm{MoO}_{2}$ by $\mathrm{H}_{2}$. Carbon oxides are formed only to a relatively low extend. At $700^{\circ} \mathrm{C}$, the formation of $\mathrm{CH}_{4}$ is detected, which can originate from both, the methanation of released $\mathrm{CO}_{x}$ and of the carbon support, respectively. Instead, when using $\mathrm{He}$ the formation of $\mathrm{CH}_{4}$ is not observed and $\mathrm{CO}_{2}$ and $\mathrm{CO}$ are the dominating gases produced, indicating that the reduction of $\mathrm{Mo}(\mathrm{VI})$ occurs via gasification of the carbon support.
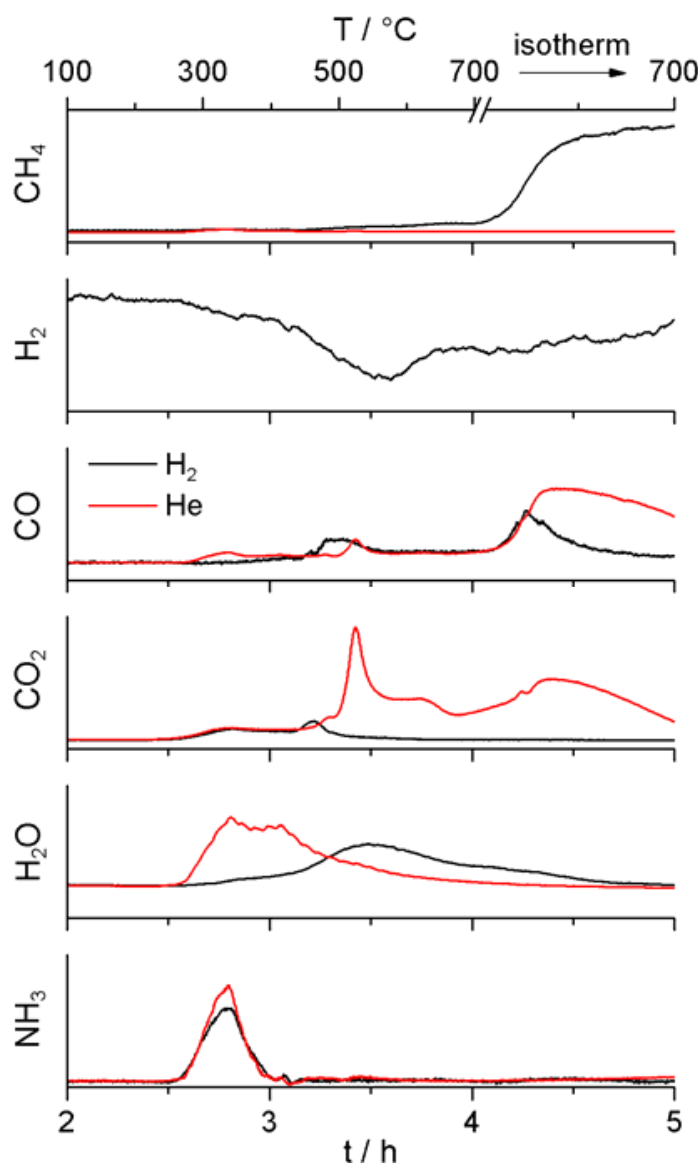

Figure 8. Profiles of $\mathrm{H}_{2}$ consumption as well as of $\mathrm{CH}_{4}, \mathrm{CO}, \mathrm{CO}_{2}, \mathrm{H}_{2} \mathrm{O}$, and $\mathrm{NH}_{3}$ formation during the carburization of $20 \mathrm{MoC} / \mathrm{oCNT}$ in $\mathrm{H}_{2}$ and in $\mathrm{He}$ at $5 \mathrm{~K} \mathrm{~min}^{-1}$, respectively.

The CO TPD experiments after carburization in $\mathrm{H}_{2}$ and $\mathrm{He}$ show much less adsorption sites on the catalysts (Tab. 1, Fig. 9). This, however, originates from the mode of operation, i.e., the TPD starting at ambient temperature. Apparently, the profile is shifted to lower T upon alloying, making low-T desorption invisible in the set-up applied. Thus, the curves shown in Fig. 9 represent only the high-T shoulder of the whole profile. In particular, only 143 and $66 \mu \mathrm{mol} g(\mathrm{Mo})^{-1}$ can be detected, respectively, as compared to $332 \mu \mathrm{mol} \mathrm{g}(\mathrm{Mo})^{-1}$ after carburization in $\mathrm{CH}_{4} / \mathrm{H}_{2}$. Again, two peaks are observed, however, the low-temperature contribution provides a much higher fraction of the overall profile. With regard to above assumptions it can be concluded that the only 25 and $20 \%$ of $\mathrm{CO}$ adsorption sites represent a Ctermination of the $\mathrm{Mo}_{\mathrm{x}} \mathrm{C}$ surface. This is plausible if we consider the hydrocarbon-free carburization atmosphere. 


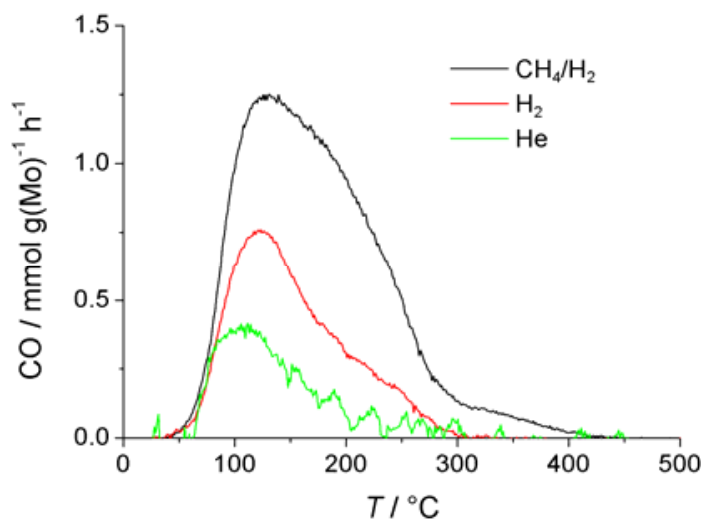

Figure 9. CO TPD profiles of $20 \mathrm{MoC} / \mathrm{OCNT}$ catalysts carburized in different atmospheres at $5 \mathrm{~K} \mathrm{~min}^{-1}$.

The catalytic performances also strongly depend on the carburization atmosphere. The catalyst carburized in pure $\mathrm{H}_{2}$ is slightly more active than those carburized in $\mathrm{CH}_{4} / \mathrm{H}_{2}$. Instead, the carburization in inert $\mathrm{He}$ yields a poorly active catalyst. The microstructural changes are also reflected in the $\mathrm{CO}_{2} / \mathrm{CH}_{4}$ product ratios. The catalytic data are assembled in Tab. 3 and in the Supporting Information, Fig. S5 The apparent activation energy of $\mathrm{CO}_{2}$ formation drops to 87 and $88 \mathrm{~kJ} \mathrm{~mol}^{-1}$ after carburization in $\mathrm{H}_{2}$ and $\mathrm{He}$, respectively, whereas the apparent activation energy of $\mathrm{CH}_{4}$ formation changes to 105 and $128 \mathrm{~kJ} \mathrm{~mol}^{-1}$, respectively. Consequently, for both alternative carburization atmospheres the $\mathrm{CO}_{2} / \mathrm{CH}_{4}$ product ratio remarkably increases and reaches a value as high as 9.2 after carburization in $\mathrm{He}$.

Table 3. SRM performance data of $20 \mathrm{MoC} / \mathrm{oCNT}$ catalysts carburized at $5 \mathrm{~K}$ $\mathrm{min}^{-1}$ in different atmospheres.

\begin{tabular}{llll} 
Atmosphere & $E_{\mathrm{a}, \mathrm{CO} 2} / \mathrm{kJ} \mathrm{mol}^{-1}$ & $E_{\mathrm{a}, \mathrm{CH} 4} / \mathrm{kJ} \mathrm{mol}^{-1}$ & $S\left(\mathrm{CO}_{2}\right) / S\left(\mathrm{CH}_{4}\right)^{[\mathrm{a}]}$ \\
\hline $20 \% \mathrm{CH}_{4} / \mathrm{H}_{2}$ & $94 \pm 2$ & $108 \pm 2$ & 4.1 \\
$\mathrm{H}_{2}$ & $87 \pm 1$ & $105 \pm 1$ & 6.2 \\
$\mathrm{He}$ & $88 \pm 1$ & $128 \pm 1$ & 9.2 \\
\hline
\end{tabular}

[a] $250^{\circ} \mathrm{C}, \mathrm{X}(\mathrm{MeOH})=50 \%$.

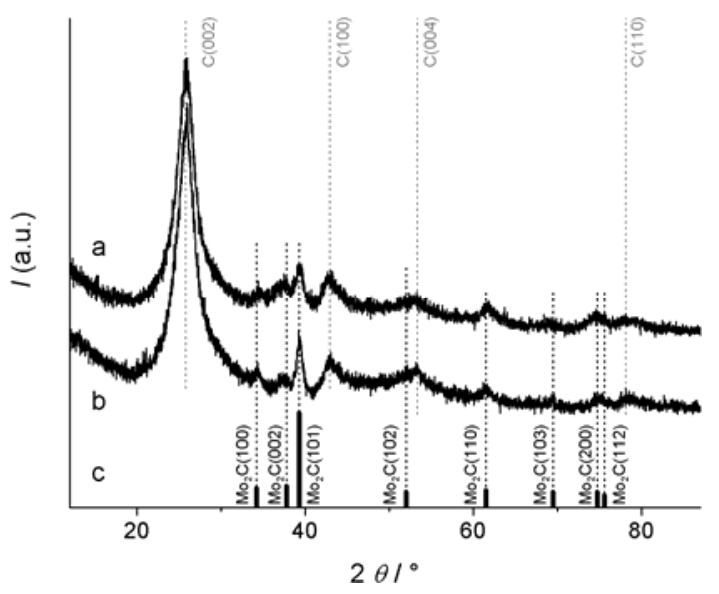

Figure 10. X-ray diffractograms of $20 \mathrm{Mo} / \mathrm{oCNT}$ catalysts carburized (a) in $\mathrm{H}_{2}$ and (b) in He after catalytic reaction; c) Reference pattern of $\beta-\mathrm{Mo}_{2} \mathrm{C} .{ }^{[40,41]}$
The reason for changes in the catalytic behaviour is poorly explained in the textural properties: catalysts carburized in $\mathrm{H}_{2}$ and He provide specific surface areas of 170 and $146 \mathrm{~m}^{2} \mathrm{~g}^{-1}$, which are quite close to the reference value of $163 \mathrm{~m}^{2} \mathrm{~g}^{-1}$ obtained by carburization in $\mathrm{CH}_{4} / \mathrm{H}_{2}$ (Tab. 1). Besides $\mathrm{CO}$ TPD the most drastic change is seen in the XRD patterns of the catalysts (Fig. 10). Both the $\mathrm{H}_{2}$ and $\mathrm{He}$ carburized samples show the typical bands of hcp $\beta-\mathrm{Mo}_{2} \mathrm{C}$ in addition to the pattern of graphitic CNTs. Its mean crystallite sizes are 8 and $10 \mathrm{~nm}$ after carburization in $\mathrm{H}_{2}$ and $\mathrm{He}$, respectively, which confirm the larger particle sizes estimated by CO TPD. Moreover, the $\mathrm{H}_{2}$ carburized sample shows a band at $\sim 38^{\circ}$, which could tentatively be interpreted as $\alpha$-MoC or oxycarbide with a crystallite diameter of $\sim 3 \mathrm{~nm}$. If we consider the gases evolved during carburization, the formation of $\alpha-\mathrm{MoC}$ on this sample could possibly be related with the presence of $\mathrm{CH}_{4}$ at the end of the carburization process. Instead, on the $\mathrm{He}$ carburized sample a considerable amount of $\sim 20 \% \mathrm{MoO}_{2}$ is detected (Fig. 10). Metallic Mo is identified on none of the XRD patterns.

The (partial) carburization of $\mathrm{AHM}$ in inert $\mathrm{He}$ at $700^{\circ} \mathrm{C}$ is a surprising result, as the temperatures required for such solid state reactions are typically much higher. ${ }^{[8,9]}$ Taking the large crystallite size of remaining $\mathrm{MoO}_{2}$ into account, the problem for incomplete reduction might be the Mo dispersion at elevated temperature. However, taking these differences in phase composition of the catalysts into account, the different catalytic performances (Tab. 3 , Supporting information, Fig. S5) are not surprising. Results of the loading series and the variation of carburization atmosphere suggest that the formation of $\mathrm{CO}_{2}$ and $\mathrm{CH}_{4}$ could possibly be related with the $\mathrm{Mo}_{\mathrm{x}} \mathrm{C}$ surface terminations by $\mathrm{Mo}$ and $\mathrm{C}$, respectively.

\section{Conclusion}

The preparation, characterization and catalytic testing of CNT-supported molybdenum carbide catalysts are presented. It is suggested that the nature of the $\mathrm{Mo}_{\mathrm{x}} \mathrm{C}$ crystal phase is a sensitive function of the highly defective state of the CNT support structure, which kinetically controls the formation of favorable crystallization nuclei leading to a stabilized polycrystalline catalyst. The pervasive carburization can be controlled by the carburization atmosphere. The carburization at $700^{\circ} \mathrm{C}$ in $\mathrm{CH}_{4} / \mathrm{H}_{2}$ yields $\alpha-\mathrm{MoC}$, whereas in pure $\mathrm{H}_{2}$ a mixture of $\alpha-\mathrm{MoC}$ and $\beta-\mathrm{Mo}_{2} \mathrm{C}$ is formed. In inert $\mathrm{He}$ only the $\beta-\mathrm{Mo}_{2} \mathrm{C}$ phase is formed, however, somewhat higher temperatures that $700^{\circ} \mathrm{C}$ are required according to the synthesis route applied in this study. The heating rate during carburization was found to be less important for the catalyst structure and reactivity. The $\mathrm{Mo}_{x} \mathrm{C}$ particle size as estimated by CO TPD steadily increases with the $\mathrm{Mo}_{x} \mathrm{C}$ loading from 5 to 30 wt $\%$. Instead the crystallite size as given by XRD analysis remains constant at $\sim 2 \mathrm{~nm}$ for $\alpha-\mathrm{MoC}$ and $<10 \mathrm{~nm}$ for $\beta-\mathrm{Mo}_{2} \mathrm{C}$ (note: volume-average). The CO TPD reveals two contributions, which are tentatively assigned to Mo and $C$ terminated surfaces. According to this the fraction of $C$ termination increases with the increasing $\mathrm{Mo}_{x} \mathrm{C}$ loading, however, sharply decreases when using a $\mathrm{CH}_{4}$-free carburization atmosphere.

The materials synthesized are highly active and stable catalysts in the SRM reaction. Here, the activity and product selectivity sensitively depend on the $\mathrm{Mo}_{\mathrm{x}} \mathrm{C}$ loading and crystal phase. Probably also the surface termination by Mo or $\mathrm{C}$ plays an important role.

The experiments performed provide a versatile toolbox for the synthesis of differently performing catalysts, not only for SRM. It 
is expected that trends and dependencies presented in this study to control the catalyst properties also provide important parameters to modify the activity and selectivity of CNT supported $\mathrm{Mo}_{\mathrm{x}} \mathrm{C}$ catalysts in other reactions, e.g., the Fischer Tropsch alcohol synthesis. In this way the SRM reaction was applied rather as a probe reaction than as the economically/industrially highly interesting pathway for $\mathrm{H}_{2}$ generation from liquid fuels.

\section{Experimental Section}

Synthesis: Commercial MWCNTs (Baytubes C $150 \mathrm{HP}$ ) were pretreated by refluxing in $65 \% \mathrm{HNO}_{3}(500 \mathrm{ml}$ per $10 \mathrm{~g})$ for $2 \mathrm{~h}$. The product was washed with deionized water until neutral $\mathrm{pH}$ and dried in air at $110{ }^{\circ} \mathrm{C}$ for 1 day (oCNT). Aliquots of $1 \mathrm{~g}$ oCNT were impregnated with $3 \mathrm{ml}$ of differently concentrated aqueous solutions of $\left(\mathrm{NH}_{4}\right)_{6} \mathrm{Mo}_{7} \mathrm{O}_{24} \cdot 4 \mathrm{H}_{2} \mathrm{O}$, respectively, to achieve final $\mathrm{Mo}_{\mathrm{x}} \mathrm{C}$ loadings between 5 and $30 \mathrm{wt} \%$. Accordingly, samples are denoted as $y \mathrm{MoC} / \mathrm{oCNT}$, where $y$ represents the nominal loading of $\mathrm{Mo}_{\mathrm{x}} \mathrm{C}$ in wt $\% .{ }^{[43]}$ The resulting pastes were thoroughly kneaded in a mortar followed by drying in air at $110^{\circ} \mathrm{C}$ for 1 day. In a typical carburization procedure, a catalyst mass nominally containing $0.5 \mathrm{mmol} \mathrm{Mo}$, e.g., $250 \mathrm{mg} 20 \mathrm{MoC} / \mathrm{oCNT}$, was placed in a quartz tubular reactor $(7 \mathrm{~mm}$ inner diameter) in a stream of $37 \mathrm{ml} \mathrm{min}{ }^{-1}$ of a $20 \mathrm{vol} \% \mathrm{CH}_{4} / \mathrm{H}_{2}$ mixture. After elution of $\mathrm{H}_{2} \mathrm{O}$ and $\mathrm{O}_{2}\left(1 \mathrm{~h}\right.$ at $\left.100^{\circ} \mathrm{C}\right)$ the reactor temperature was linearly increased by $5 \mathrm{~K} \mathrm{~min}^{-1}$ up to $700{ }^{\circ} \mathrm{C}$ and kept for $2 \mathrm{~h}$, followed by cooling to ambient temperature in the reducing atmosphere.

Characterization: Temperature-programmed desorption (TPD) of CO was performed immediately after carburization without passivation or air contact of the catalyst. The reactor was flushed with $5 \mathrm{vol} \% \mathrm{CO} / \mathrm{Ar}$ for $10 \mathrm{~min}$ at ambient temperature and subsequently flushed with $\mathrm{He}$ until no $\mathrm{CO}$ was detectable by on-line mass spectrometry (MS, Pfeiffer GAM 200) and gas chromatography (GC, Varian xx Micro GC). In a He stream of $30 \mathrm{ml} \mathrm{min}^{-1}$ the temperature was linearly increased by $10 \mathrm{~K} \mathrm{~min}^{-1}$ up to $700^{\circ} \mathrm{C}$. Further characterization of the catalysts was performed after catalytic testing. Passivated samples were analyzed after exposition to ambient. TEM was performed on a FEI Cs-corrected Titan 80-300 microscope (300 kV) and SEM images were obtained on a Hitachi S-4800 FEG microscope $(1.5 \mathrm{kV})$ equipped with an EDAX Genesis EDX detector (15 kV). The XRD measurements were performed on a Bruker AXS D8 Advance diffractometer equipped with a secondary graphite monochromator ( $\mathrm{Cu} \mathrm{K \alpha _{1+2 }}$ radiation) and scintillation detector. Crystallite size values were extracted by full pattern fitting and are reported as $\mathrm{L}_{\mathrm{vol}} \mathrm{I}$ IB values (volume weighted mean column length based on integral breadth) without further assumptions concerning crystallite shape or size distribution. $\mathrm{N}_{2}$ physisorption was performed at $77 \mathrm{~K}$ in the relative pressure range of $p / p 0=0.05-0.3$ after drying the sample in vacuum at $200^{\circ} \mathrm{C}$ for $2 \mathrm{~h}$..

Catalytic testing: Catalysts were tested for their catalytic performance in the steam reforming of methanol (SRM) at $250^{\circ} \mathrm{C}$ in $100 \mathrm{ml} \mathrm{min}{ }^{-1}$ of a 2 vol\% $\mathrm{CH}_{3} \mathrm{OH} / 2$ vol\% $\mathrm{H}_{2} \mathrm{O} / \mathrm{He}$ mixture. After $2 \mathrm{~h}$ on stream, the flow rate was varied between 100 and $10 \mathrm{ml} \mathrm{min}^{-1}$, followed by decreasing the temperature in $10 \mathrm{~K}$ steps to $200{ }^{\circ} \mathrm{C}$ at $100 \mathrm{ml} \mathrm{min}^{-1}$. Reaction products were quantified by $\mathrm{GC}$ analysis. Contact of the catalyst with $\mathrm{H}_{2} \mathrm{O}$ (reactant) and $\mathrm{CO}_{2}$ (product) ensured the mild passivation of the $\mathrm{Mo}_{x} \mathrm{C}$ surface, which is required prior to final exposure of the catalyst to ambient for its characterization.

\section{Acknowledgements}

The authors thank W. Frandsen, F. Rybicki, G. Weinberg, and Z.L. Xie for experimental assistance. Financial support by the
Federal Ministry of Education and Research (BMBF) within the CarboKat project (FKZ 03X0204C) of the Inno.CNT alliance is gratefully acknowledged.

Keywords: molybdenum carbide $\cdot$ crystal phase $\cdot$ surface termination $\bullet$ steam reforming of methanol $\bullet \mathrm{CO}$ TPD

[1] R. B. Levy, M. Boudart, Science 1973, 181, 547-549.

[2] S. T. Oyama, in Handbook of Heterogeneous Catalysis (Eds.: G. Ertl, H. Knözinger, F. Schüth, J. Weitkamp), Wiley VCH, 2008, pp. 342-356.

[3] J. S. Lee, S. T. Oyama, M. Boudart, J. Catal. 1987, 106, 125-133.

[4] A. J. Brungs, A. P. E. York, J. B. Claridge, C. Márquez-Alvarez, M. L. H. Green, Catal. Lett. 2000, 70, 117-122.

[5] R. Barthos, A. Széchenyi, F. Solymosi, Catal. Lett. 2008, 120, 161-165.

[6] X. Li, D. Ma, L. Chen, X. Bao, Catal. Lett. 2007, 116, 63-69.

[7] C. Sayag, M. Benkhaleda, S. Suppanb, J. Trawczynskib, G. DjégaMariadassoua, Appl. Catal. A 2004, 275, 15-24.

[8] J. Han, J. Duan, P. Chen, H. Lou, X. Zheng, H. Hong, ChemSusChem 2012, 5, 727-733.

[9] H. Wang, A. Wang, X. Wang, T. Zhang, Chem. Commun. 2008, 25652567.

[10] R. Barthos, A. Széchenyi, Á. Koós, F. Solymosi, Appl. Catal. A 2007, 327, 95-105.

[11] J. Haber, T. Machej, R. Grabowski, Solid State lonics 1989, 32-33, Part 2, 887-892.

[12] Y.-C. Xie, Y.-Q. Tang, in Advances in Catalysis, Academic Press, 1990, pp. 1-43.

[13] T. Cotter, The Reducibility of Mixed Mo/V Oxide Materials to Carbides and Their Reactivity in the Activation of Propane, Technische Universität Berlin, 2011.

[14] A. Hanif, T. Xiao, A. P. E. York, J. Sloan, M. L. H. Green, Chem. Mater. 2002, 14, 1009-1015.

[15] R. Schlögl, in Handbook of Heterogeneous Catalysis (Eds.: G. Ertl, H Knözinger, F. Schüth, J. Weitkamp), Wiley VCH, 2008, pp. 2501-2575.

[16] E. J. Markel, J. W. Van Zee, J. Catal. 1990, 126, 643-657.

[17] C. H. Jaggers, J. N. Michaels, A. M. Stacy, Chem. Mater. 1990, 2, 150 157

[18] J. G. Choi, J. R. Brenner, L. T. Thompson, J. Catal. 1995, 154, 33-40.

[19] S. T. Oyama, J. C. Schlatter, J. E. Metcalfe, J. M. Lambert, Ind. Eng. Chem. Res. 1988, 27, 1639-1648.

[20] J. L. Figueiredo, M. F. R. Pereira, Catal. Today 2010, 150, 2-7.

[21] D. W. McKee, Carbon 1970, 8, 623-635.

[22] J.-W. Dun, E. Gulari, B. Streusand, Appl. Catal. 1986, 21, 61-72.

[23] A. Rinaldi, J.-P. Tessonnier, M. E. Schuster, R. Blume, F. Girgsdies, Q. Zhang, T. Jacob, S. B. Abd Hamid, D. S. Su, R. Schlögl, Angew. Chem. Int. Ed. 2011, 50, 3313-3317.

[24] S. Yang, C. Li, J. Xu, Q. Xin, J. Phys. Chem. B 1998, 102, 6986-6993.

[25] X.-R. Shi, J. Wang, K. Hermann, J. Phys. Chem. C 2010, 114, 13630 13641.

[26] S. Ramanathan, S. T. Oyama, J. Phys. Chem. 1995, 99, 16365-16372.

[27] Assumptions: spherical geometry, MoxC density $=8.2 \mathrm{~g} \mathrm{~cm}-3$, CO site density $1015 \mathrm{~cm}-2$., n.d.

[28] Á. Mastalir, Á. Patzkó, B. Frank, R. Schomäcker, T. Ressler, R. Schlögl, Catal. Commun. 2007, 8, 1684-1690

[29] M. Saito, R. B. Anderson, J. Catal. 1980, 63, 438-446.

[30] B. Frank, F. C. Jentoft, H. Soerijanto, J. Kröhnert, R. Schlögl, R. Schomäcker, J. Catal. 2007, 246, 177-192.

[31] R. Barthos, F. Solymosi, J. Catal. 2007, 249, 289-299.

[32] S. S.-Y. Lin, W. J. Thomson, T. J. Hagensen, S. Y. Ha, Appl. Catal. A 2007, 318, 121-127.

[33] W. Wu, Z. Wu, C. Liang, P. Ying, Z. Feng, C. Li, Phys. Chem. Chem. Phys. 2004, 6, 5603.

[34] I. F. Ferguson, J. B. Ainscough, D. Morse, A. W. Miller, Nature 1964, 202 1327-1328.

[35] O. Matsumoto, Y. Yaguchi, Y. Shiota, Y. Kanzaki, High Temp. Sci. 1983, 16, 243-250

[36] H. O. Pierson, in Handbook of Refractory Carbides \& Nitrides, Noyes Publications, New Jersey, 1997, pp. 110-112.

[37] C. Bouchy, I. Schmidt, J. . Anderson, C. J. Jacobsen, E. Derouane, S. Derouane-Abd Hamid, J. Mol. Catal. A 2000, 163, 283-296.

[38] J. S. Lee, L. Volpe, F. H. Ribeiro, M. Boudart, J. Catal. 1988, 112, 44-53.

[39] G. S. Ranhotra, A. T. Bell, J. A. Reimer, J. Catal. 1987, 108, 40-49.

[40] J. Liu, J. Shen, X. Gao, L. Lin, J. Therm. Anal. Calorim. 1993, 40, 1245 1252.

[41] Inorganic Crystal Structure Database, URL: http://icsd.fkf.mpg.de/, n.d.

[42] E. Parthé, V. Sadogopan, Acta Cryst. 1963, 16, 202-205.

[43] FHI internal sample numbers in parentheses: 05MoC/oCNT (13894); $10 \mathrm{MoC} / \mathrm{oCNT}$ (13896); 20MoC/oCNT (13898 and 13899); 30MoC/oCNT (13901)

05MoC/oCNT (13894); 10MoC/oCNT (13896); 20MoC/oCNT (13898 and 13899); 30MoC/oCNT (13901). 
Received: ((will be filled in by the editorial staff))

Published online: ((will be filled in by the editorial staff)) 


\section{Entry for the Table of Contents}

\section{FULL PAPER}

The synthesis of CNT-supported $\alpha-\mathrm{MoC}$ and $\beta-\mathrm{Mo}_{2} \mathrm{C}$ nanoparticles can be controlled by the carburization conditions applied. The impact of Mo loading, heating rate of carburization and carburization atmosphere as well as their impact on the catalytic performance of resulting Mo carbide catalysts in the steam reforming of methanol are discussed.

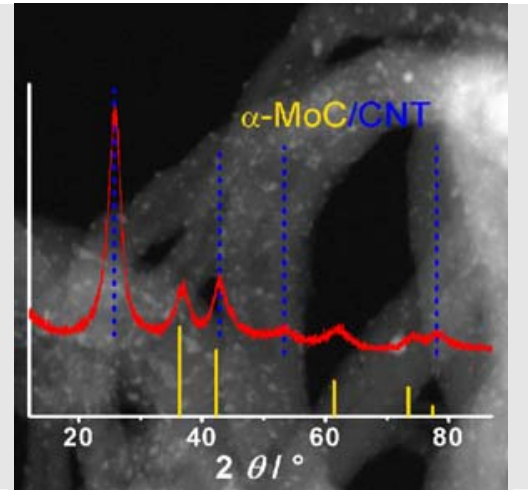

Benjamin Frank, Klaus Friedel, Frank Girgsdies, Xing Huang, Robert Schlögl, and Annette Trunschke*

Page No. - Page No.

CNT supported $\mathrm{Mo}_{\mathrm{x}} \mathrm{C}$ catalysts: Impact of loading and carburization parameters 


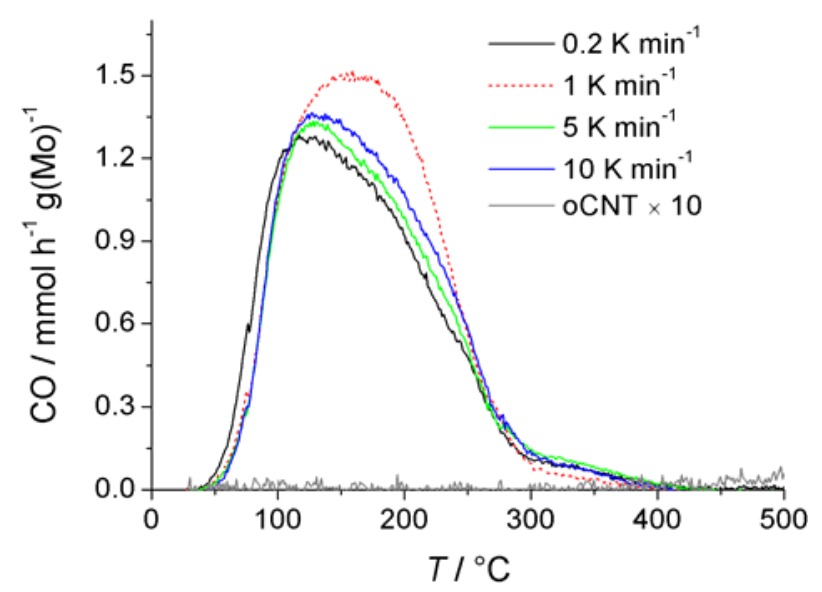

Table S1. SRM performance data of $20 \mathrm{MoC} / \mathrm{OCNT}$ catalysts carburized at different heating rates in $\mathrm{CH}_{4} / \mathrm{H}_{2}$.

\begin{tabular}{|llll|}
$\beta$ & $\begin{array}{l}E_{\mathrm{a}}\left(\mathrm{CO}_{2}\right) \\
/ \mathrm{min}^{-1}\end{array}$ & $\begin{array}{l}E_{\mathrm{a}}\left(\mathrm{KH}_{4}\right) \\
/ \mathrm{kJ} \mathrm{mol}^{-1}\end{array}$ & $S\left(\mathrm{CO}_{2}\right) / S\left(\mathrm{CH}_{4}\right)^{[\mathrm{a}]}$ \\
\hline 0.2 & $91 \pm 3$ & $108 \pm 1$ & 5.1 \\
1 & $95 \pm 1$ & $108 \pm 1$ & 4.2 \\
5 & $94 \pm 2$ & $108 \pm 2$ & 4.1 \\
10 & $92 \pm 2$ & $108 \pm 1$ & 4.2 \\
\hline
\end{tabular}

[a] $250^{\circ} \mathrm{C}, X(\mathrm{MeOH})=50 \%$.

Figure S1. CO TPD profiles of 20MoC/oCNT catalysts ( $T$ ramping series). The increased intensity of the $1 \mathrm{~K} \mathrm{~min}^{-1}$ profile is most likely due to an experimental error.
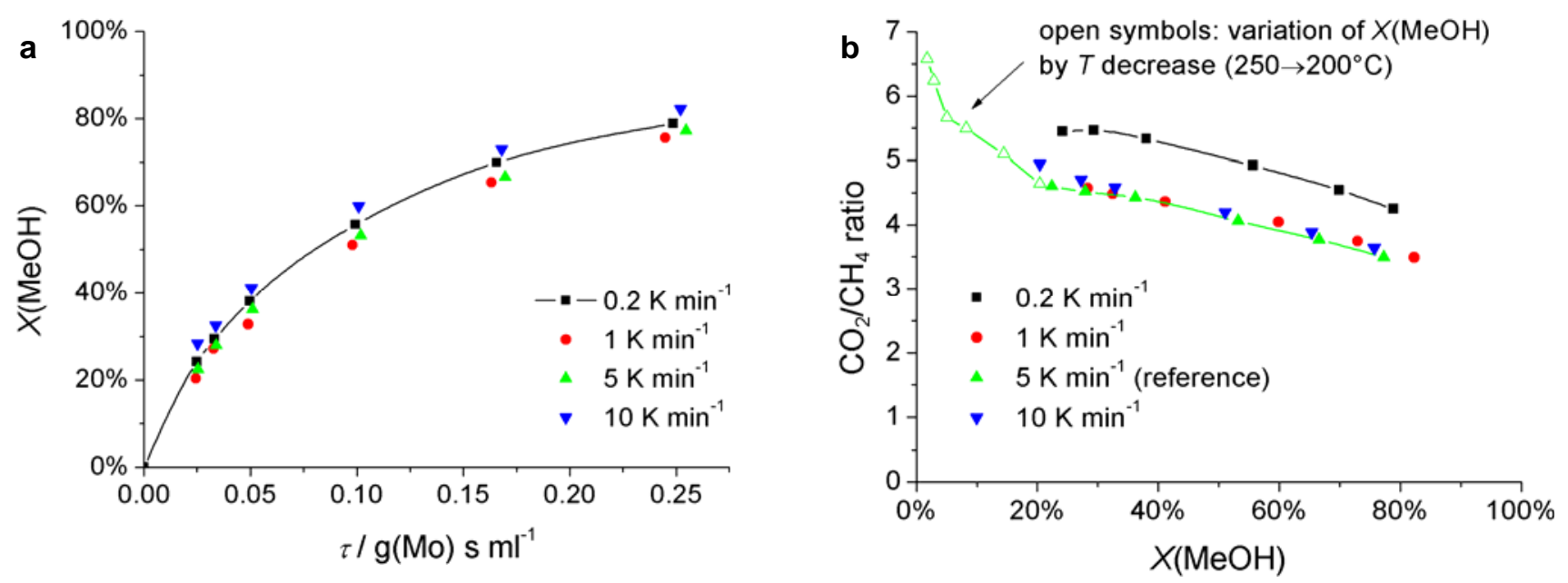

Figure S2. Catalytic performances of $20 \mathrm{MoC} / \mathrm{oCNT}$ catalysts ( $T$ ramping series) in the SRM reaction. (a) MeOH conversion as a function of Mo-based contact time, (b) $\mathrm{CO}_{2} / \mathrm{CH}_{4}$ product ratio as a function of $\mathrm{MeOH}$ conversion. $10-100 \mathrm{ml} \mathrm{min}^{-1} 1 \% \mathrm{MeOH} / 1 \% \mathrm{H}_{2} \mathrm{O} / \mathrm{He}, 250^{\circ} \mathrm{C}$.
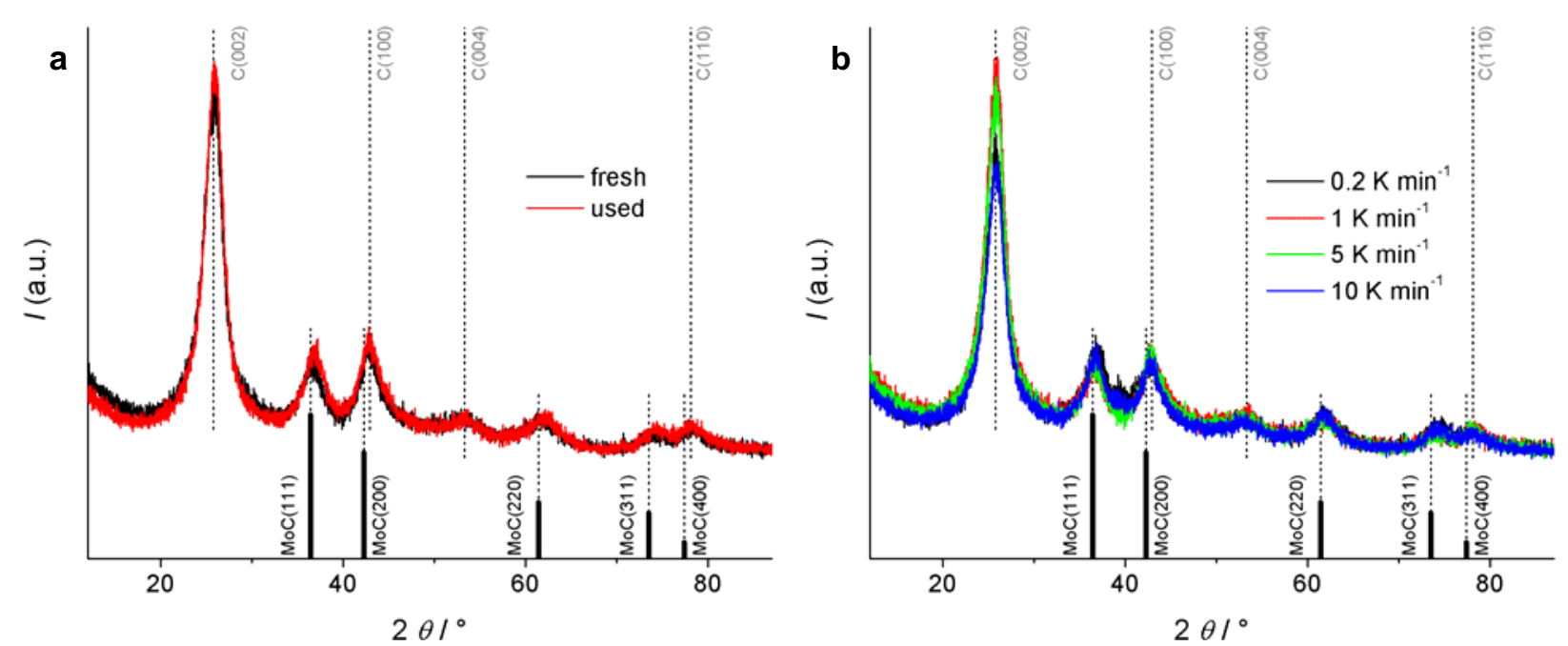

Figure S3. XRD patterns of $20 \mathrm{MoC} / \mathrm{OCNT}$ catalysts (a) before and after catalytic reaction and (b) carburized at different heating rates in $20 \% \mathrm{CH}_{4} / \mathrm{H}_{2}$ (the fresh $20 \mathrm{MoC}$-oCNT sample has the $\mathrm{FHI}$ internal sample number 13942). 

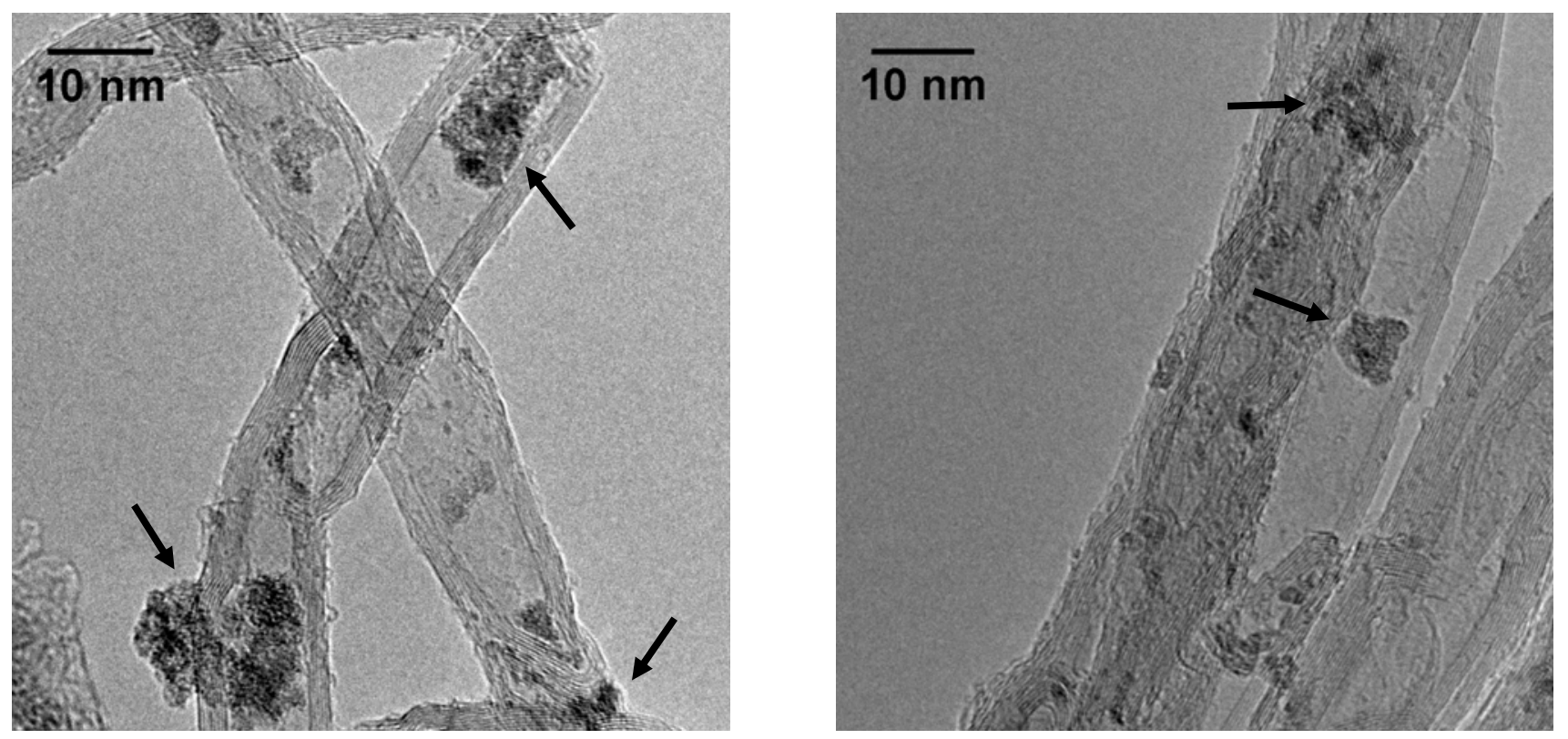

Figure S4. TEM images of high loaded $20 \mathrm{MoC} / \mathrm{oCNT}$ catalyst showing agglomeration of $\mathrm{Mo}_{\mathrm{x}} \mathrm{C}$ crystallites (arrows).
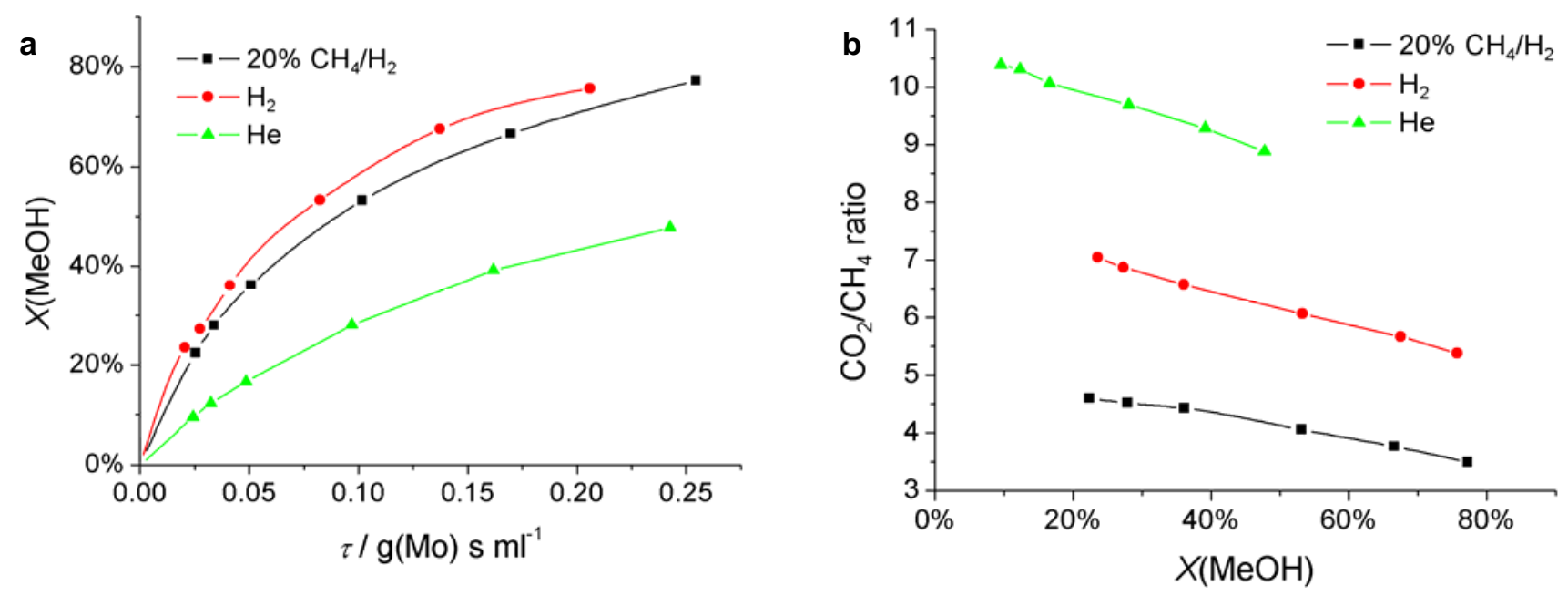

Figure S5 Catalytic performances of 20MoC/oCNT catalysts (atmosphere series) in the SRM reaction. (a) MeOH conversion as a function of Mo-based contact time, (b) $\mathrm{CO}_{2} / \mathrm{CH}_{4}$ product ratio as a function of MeOH conversion. $10-100 \mathrm{ml} \mathrm{min}{ }^{-1} 1 \% \mathrm{MeOH} / 1 \% \mathrm{H}_{2} \mathrm{O} / \mathrm{He}, 250^{\circ} \mathrm{C}$. 